DANMARKS GEOLOGISKE UNDERSøGELSE

Serie B, Nr. 2

Geological Survey of Denmark. Serie B, No. 2

\title{
Stratigraphy and distribution of Jurassic deposits of the Norwegian-Danish Basin
}

\author{
BY
}

Olaf Michelsen

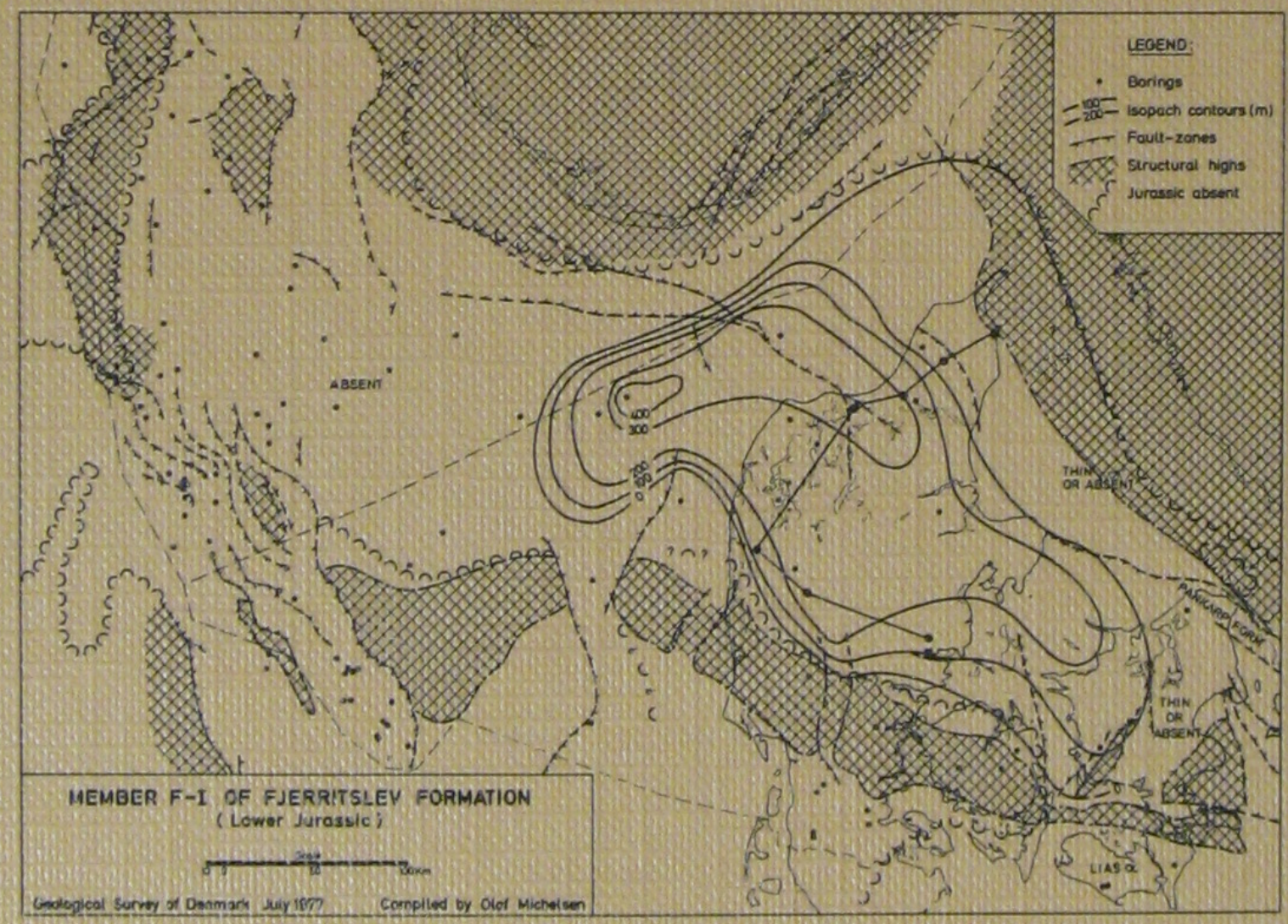

I kommission hos C. A. Reitzels Forlag . København 1978 
Danmarks Geologiske Undersøgelse. Serie B, Nr. 2

Geological Survey of Denmark. Series B, No. 2

\section{Stratigraphy and}

\section{distribution of Jurassic deposits of \\ the Norwegian-Danish Basin}

by

Olaf Michelsen

I kommission hos C. A. Reitzels Forlag. København 1978 
D.G.U. Serie B, nr. 2

er sat med Foto Times

og trykt i offset i 1000 eksemplarer

hos Andelsbogtrykkeriet i Odense.

Bogen er trykt på Thai-Cote, $115 \mathrm{~g}$

fra a/s De forenede Papirfabrikker.

ISBN 87-421-0712-1

Date of publication: 1978-03-31

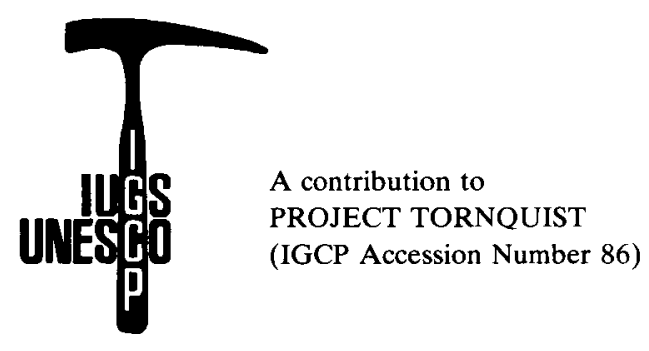




\section{Contents}

Abstract $\ldots \ldots \ldots \ldots \ldots \ldots \ldots \ldots \ldots \ldots, 4$

Introduction $\ldots \ldots \ldots \ldots \ldots \ldots \ldots \ldots, 4$

Lower Jurassic .................... 9

Fjerritslev Formation ................. 9

Member F-I .................... 14

Member F-II ..................... 14

Member F-III .................... 15

Member F-IV .................. 15

The Fjerritslev/Haldager

Formation boundary .............. 15

Basinal development ................. 15

Middle Jurassic . . ..................... 16

Haldager Formation .................. 16

Haldager Sand ................... 16

Flyvbjerg Member ................... 18

Basinal development .................. 19

Upper Jurassic ...................... 20

Bream Formation .................. 20

Børglum Member............... 20

Frederikshavn Member.............. 23

Basinal development .................. 23

Summary .......................... 24

Acknowledgements .................. 25

Dansk sammendrag ................... 25

References....................... 28 


\section{Abstract}

The lithostratigraphical subdivision of the Jurassic deposits in the Norwegian-Danish Basin is revised. The Fjerritslev Formation is emended and divided into four members. The Haldager formation is emended and divided into two members. It is proposed to include the Skagen Formation in the Frederikshavn Member, which together with the Børglum Member is included in the Bream Formation. Isopach maps of the individual lithostratigraphical units are presented. The sedimentary history of the basin is described.

\section{Introduction}

Jurassic deposits of the Norwegian-Danish Basin have previously been described from different parts of the area by several authors (Sorgenfrei \& Buch 1964, Sorgenfrei 1969, Larsen 1966, Christensen 1974, Michelsen 1975, Younge et al. 1975).

Larsen (1966) is the first to make a lithostratigraphical subdivision of the Triassic, Jurassic, and Lower Cretaceous sediments in the Danish Subbasin. He erected the formations dealt with in the present paper on the basis of the sedimentary macro-cycles, but without using wire line logs for definition of the boundaries. The stratigraphy was poorly known at that time. As the wire line logs were of poor quality and they were not used for describing the sedimentary characters and facies. It is therefore necessary to revise the lithostratigraphy and, especially, to redefine the formational boundaries. Recently, Deegan \& Scull (1977) described the lithostratigraphy of the sediments in the central and northern North Sea. They use Larsen's (1966) lithostratigraphical units uncritically.

As Deegan \& Scull (1977) comprises lithostratigraphical descriptions of sediments from the entire central North Sea area, including the Norwegian-Danish Basin, some comments must be given: 1) The co-operation of the Norwegian and the Danish Jurassic sub-committees so far has only extended to a few initial working-meetings. Therefore, the agreement mentioned in their paper (p. 21) should not be emphasized as a final decision.

2) The Gassum Formation is time-transgressive from Upper Triassic to Late Sinemurian (cf. Michelsen 1975) and not as shown in their table 2 (p. 10).
3) The Fjerritslev Formation is of Hettangian to Aaalenian age in the central part of the Danish Subbasin (Michelsen 1975) and not as shown in their table 2 (pl. 10), nor as described on p. 21. Since the formation is only found in the Danish Subbasin and since there are no determinations of the lower part of the Haldager Formation giving an age younger than Middle Jurassic in that area, the unconformity should only comprise the upper part of Lower Jurassic. According to their description (p. 22) a Kimmeridgian age for the Haldager Formation is only known from the western and southwestern part of the basin.

4) When they describe the Haldager Formation as lacustrine to fluvial in the eastern and northeastern part of the basin this must be within the Norwegian section, and it may be the series dealt with p. 8. For the Danish sector see below.

5) Since they do not revise the Haldager Formation, a comparison and correlation should have been made of their Egersund Member and the upper part of the formation (the Flyvbjerg Member in the present paper). The log patterns of the series published by Deegan $\&$ Scull are not typical for the Haldager Formation, but may represent equivalent series (see also below).

6) Definition and description of the Bream Formation, which comprises the Børglum and Frederikshavn Member, must include sedimentary characters from the type area of the two members and not only from the type area of the formation. Furthermore, a decision regarding the Skagen and Vedsted Formations (sensu Larsen 1966) is necessary for definition of the upper boundary of the Bream Formation. A possible intercalation of the Vedsted Formation into the Frederikshavn Member (see the present paper p. 23) and the relationships between the Valhall Formation (Deegan\&Scull 1977) and the Vedsted Formation (Larsen 1966) could have been elucidated through closer co-operation.

The purpose of the present paper has been to use a compilation of data on the sedimentary characters, distribution, thickness, stratigraphy, and environmental conditions throughout the entire basin to revise the lithostratigraphy, to map the series, and to describe the development of the basin in relation to the surrounding areas.

The extent of the Norwegian-Danish Basin together with the bordering structural elements is shown in fig. 1. The basin is a part of the northern Zechstein basin. The early Kimmerian phase formed more restricted basins at the end of the Triassic.

The maps given as figs. 1, 2, 7, 9, 11-13, 15-16 have been compiled from maps, well data, and seismic data. The main structural elements are drawn from a structural map covering the Danish area, worked out by J. C. Baartman (Geological Survey of Denmark 1976, publ. in Rasmussen 1978), and from 


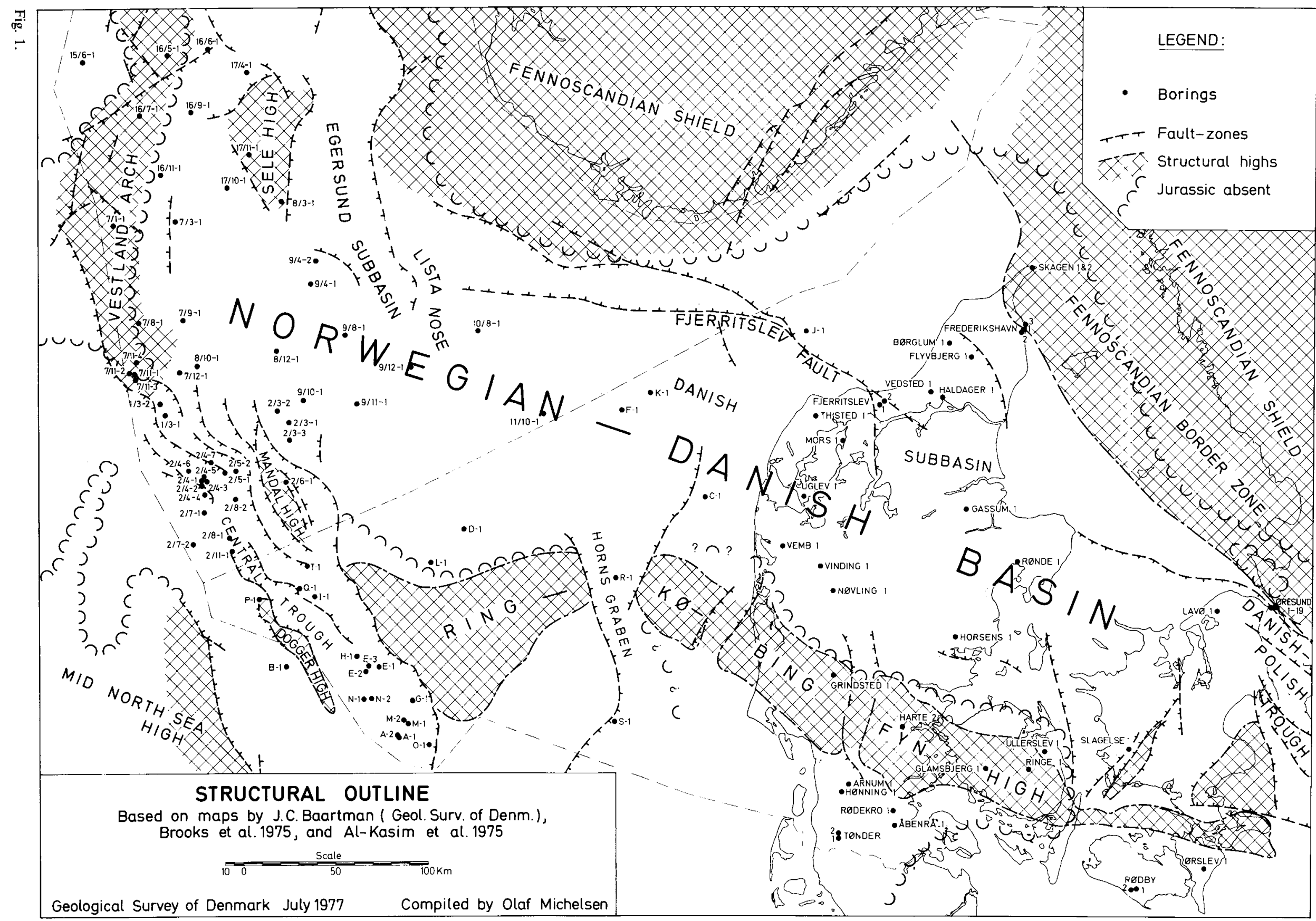




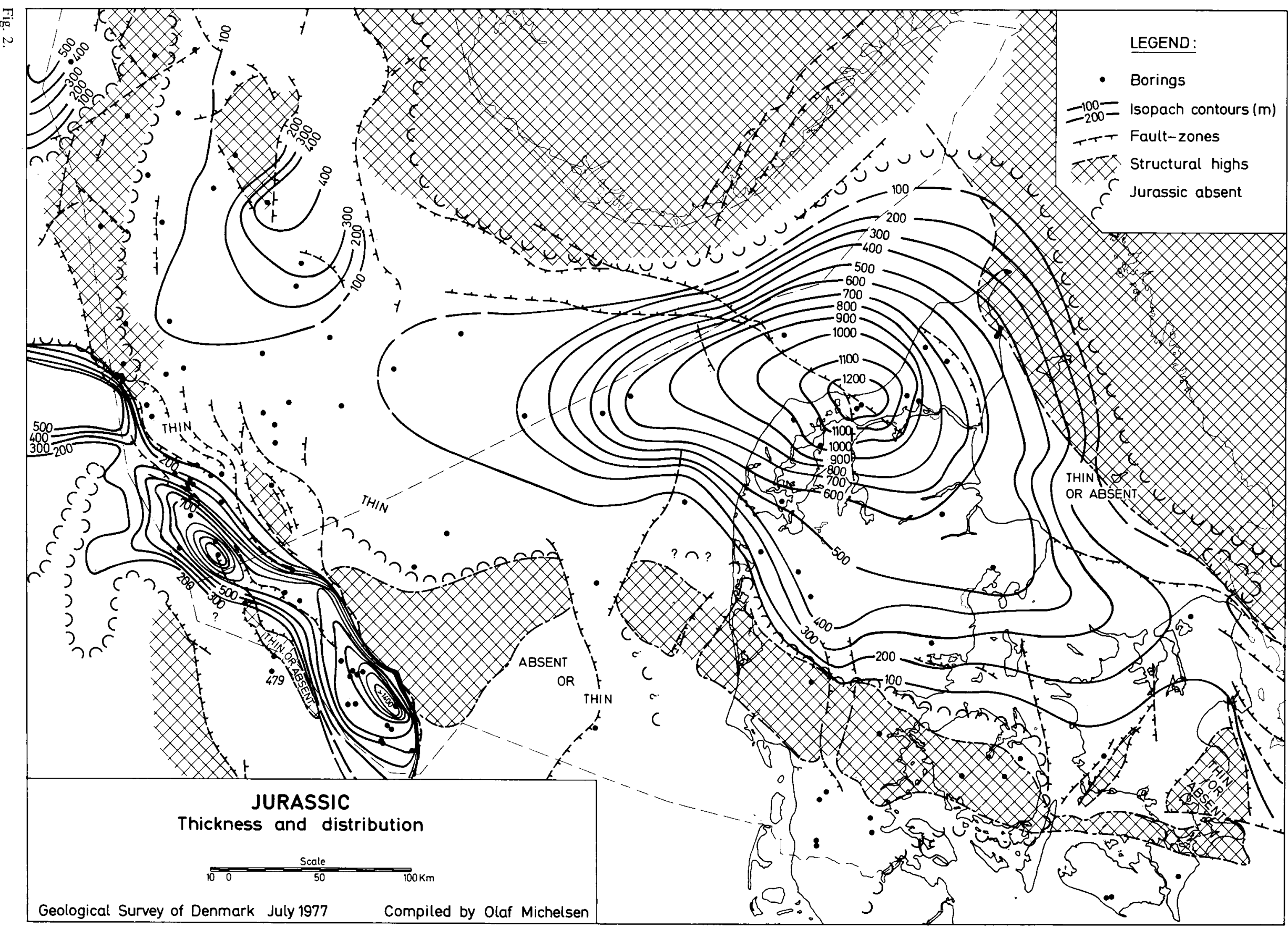




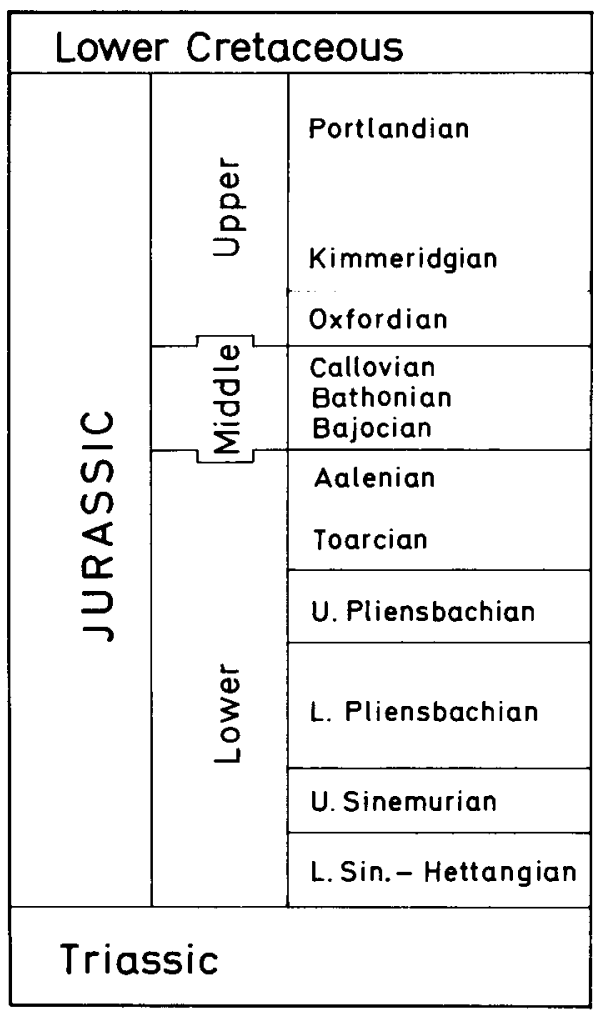

Fig. 3.

\begin{tabular}{|c|c|c|}
\hline \multirow{3}{*}{ Bream Formation } & $\begin{array}{l}\text { Frederikshavn } \\
\text { Member }\end{array}$ & $\frac{C}{B}$ \\
\hline & & A \\
\hline & Berglum Member & \\
\hline \multirow{2}{*}{ Haldager Formation } & Flyvbjerg Member & \\
\hline & Haldager Sand & \\
\hline \multirow{5}{*}{$\begin{array}{l}\text { Fjerritslev } \\
\text { Formation }\end{array}$} & Member $F-$ II & \\
\hline & Member F-III & \\
\hline & & c \\
\hline & & $\bar{a}$ \\
\hline & Member $F-I$ & b \\
\hline \multicolumn{3}{|l|}{ Gassum Formation } \\
\hline
\end{tabular}

published maps such as Rønnevik et al. (1975, fig. 1). Much of the well data from the Danish area has been interpreted by the present author. Redescription of certain cored sections has been carried out by Søren Priisholm (Geological Survey of Denmark). Well data from the adjacent areas have been taken from NPD paper Nos. 1-9, Well data summary Sheets, vol. 1-2, and Brooks et al. 1975. Seismic lines used are from the Danish area only and have been interpreted by J. C. Baartman (Geological Survey of Denmark). The contour lines on the maps are based primarily on well data (for location of the borings, see fig. 1), even though these often give minimum figures, and secondarily on seismic lines (in the Danish area). Thus the contour lines are not completely exact and detailed, but they give a general picture of the basin and of the thicknesses and distribution of the sequences. Thickening of the sequences in minor subbasins and thinning at salt structures are not included.

For definition of the lithostratigraphical units the wire line logs are used together with cores and side wall cores. From newer borings (drilled after 1965), side wall cores, gamma ray, interval transit time, SP, resistivity, and simultaneous compensated neutron formation density logs are available. From the older borings only cores, SP, and resistivity logs (rarely gamma ray logs) are available. The SP and resistivity logs are used for correlation between newer and older borings.

A redescription of all cores has been started by Søren Priisholm and the present author for a detailed evaluation of the environmental conditions, which together with seismic mapping will be published in coming papers.

The distribution and thickness of the Jurassic sequence is shown in fig. 2. The sequence pictured is the series between the Triassic-Lower Jurassic sandstone (the Gassum Formation) and the top of the sandy and silty series uppermost in the Bream Formation and thus the series may not include the entire Lower Jurassic in all regions, whereas in some regions it includes a thin series of Lower Cretaceous age. The map has been made in this way since determination of the Triassic/Jurassic and Jurassic/Cretaceous boundaries is not possible in all borings due to missing biostratigraphical indications.

The formations and members dealt with are (see also fig. 3):

Gassum Formation, a deltaic to shallow-water littoral deposition of mainly Upper Triassic age, but in certain regions comprising the Triassic/Jurassic boundary (it is therefore characterized briefly below). 
A re-evaluation of the Triassic/Jurassic boundary in the Norwegian-Danish Basin Dansk Nordsø F-1
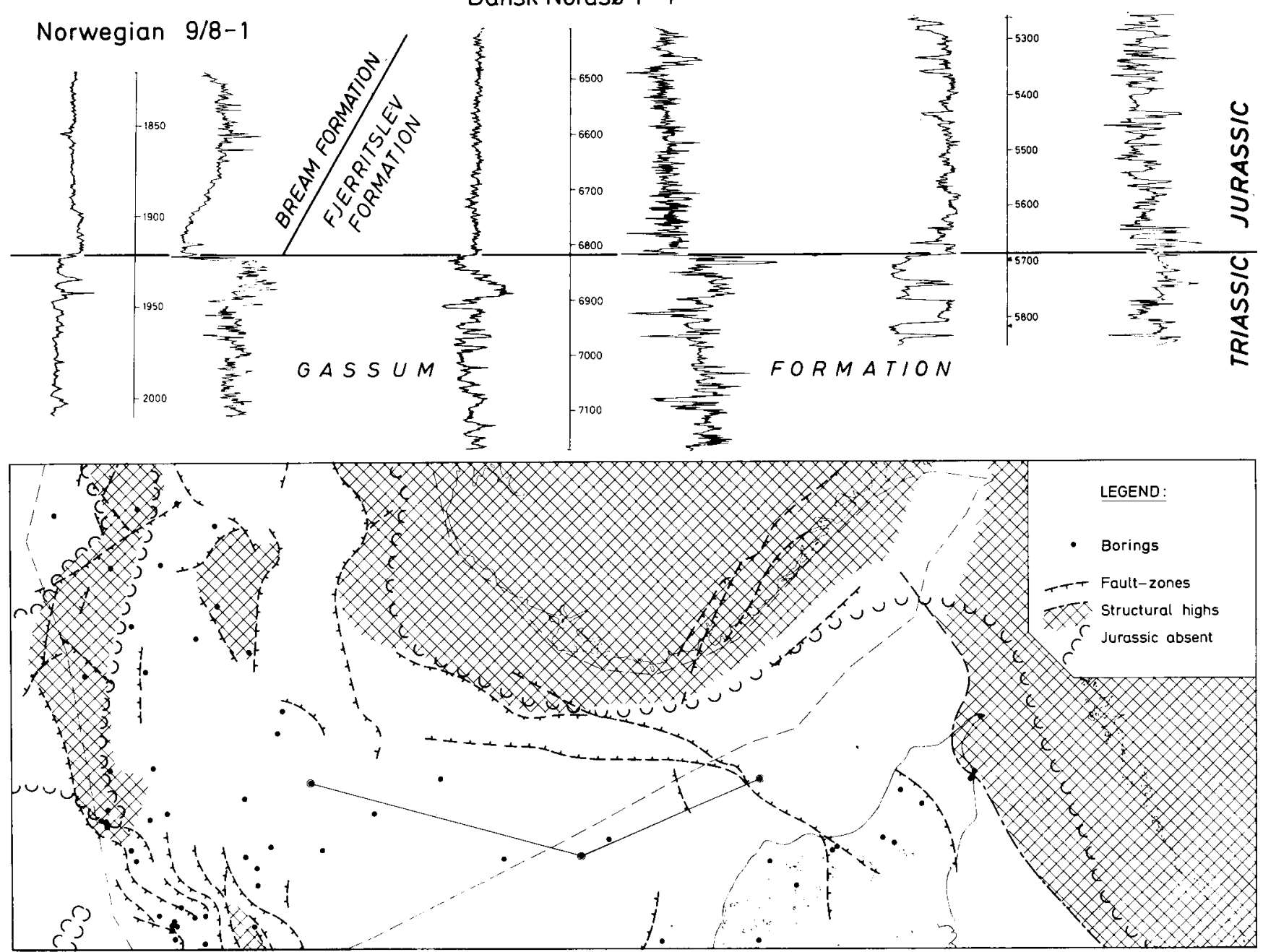

Fig. 4.

Fjerritslev Formation, a shelf deposition of shale, representing changing energy levels, of Lower Jurassic age. In most sections it can be subdivided into four members.

Haldager Formation, a deltaic coarse-grained deposition overlain by marine, shallow-water sediments; of Middle Jurassic to Oxfordian age. Subdivided into two members.

Bream Formation, a marine deposition including low energy sediments overlain by high energy near-shore sediments; of Upper Jurassic and lowest Lower Cretaceous age. Can be subdivided into two members, of which the uppermost one often comprises three sedimentary cycles.

Gassum Formation: Predominantly sand- and siltstone interbedded with claystone deposited in a deltaic and near-shore environment. The top of the formation is mappable by means of seismic methods. In the main part of the basin the series has been referred to
Upper Triassic. though biostratigraphical indications are not found in the uppermost part (Sorgenfrei \& Buch 1964, Larsen 1966, Bertelsen 1975). Ostracod faunas found in sections in the northeastern part of the basin refer at least a part of the formation in that region to Lower Jurassic (Michelsen 1975).

The series described from the Norwegian sector of the North Sea area as Middle Jurassic is regarded in the present paper as Triassic (or Triassic-Lower Jurassic) and as probably belonging to the Gassum Formation (fig. 4). Biostratigraphical indications are missing. The change of colour within the sequence is well known from the Danish onshore drilling in the Gassum Formation. Due to the close correlations in the descriptions of the sediments and in the wire line logs (see fig. 4) the series is here regarded as belonging to the Gassum Formation. However, the Egersund Member may be equivalent to the Flyvbjerg Member (see p. 19). 


\section{Lower Jurassic}

Transgressively overlying the deltaic and sub-littoral Gassum Formation is found the marine claystone or shale of the Fjerritslev Formation. These sediments were deposited during continuous subsidence of the basin. Only a minor unconformity is indicated within the sequence and it is only found locally. Studies of the ostracod faunas show that the period of sedimentation corresponds to the Lower Jurassic (Michelsen 1975).

\section{Fjerritslev Formation Emended}

History. The formation was described by Larsen (1966, pp. 29-31) without a definition of the boundaries. Concerning revision of the boundaries see below and p. 15 .

Type locality. The Fjerritslev No. 2 boring, 1314-2225 m b. MSL. (see fig. 6).

Reference section. The Dansk Nordsø J-1 boring, 1074-1697 m b. MSL. (see fig. 5).

Thickness and distribution. The maximum thickness observed in borings is found in the type section (911 $\mathrm{m}$ ), however, by means of seismic survey greater thicknesses have been proved to occur elsewhere centrally in the basin. For thickness and distribution see fig. 7 .

The formation is not supposed to be present in the western part of the basin. The log pattern of the series presented by Deegan \& Scull (1977, fig. 26) is not typical for the formation.

Lithology. The formation is a relatively uniform series of marine claystone or shale, with a varying silt-content, dark grey to black, slightly calcareous. Intercalations of sandstone and strongly calcareous beds occur (mainly proven by studies of the wire line logs). Clay-ironstone concretions are common.

Boundaries. The lower boundary is defined in newer borings primarily by the interval transit time log (see also Dansk Nordsø J-1, fig. 5). Below the boundary the curve shows a uniform series of low values belonging to the Gassum Formation, and above, generally higher values but a rather nervous curve-pattern. The gamma ray curve also determines the boundary between the clayey and shaly Fjerritslev Formation and the mainly sandy and silty Gassum Formation. The
SP and resistivity logs are used for correlation between newer and older borings.

In the type section, the lower part of the formation is not described by means of wire line logs, and therefore the lower boundary must be defined in the reference section. The lower boundary is placed higher in the type section in the present paper than in Larsen 1966 due to the occurrence of a pronounced bed of sandstone known from the cuttings samples.

The upper boundary is clearly defined by the interval transit time and gamma ray logs (in the newer borings) and by the SP and resistivity logs (in the older borings) as the boundary between the silty claystone series and the overlying sandstone series of the Haldager Formation (see figs. 6 and 13). Especially the gamma ray and SP logs clearly demonstrate the boundary. Concerning the revision and discussion of the boundary between the two formations see $p$. 15.

To the south in the basin the determination is less certain because of the absence of the upper part of the Fjerritslev Formation (see p. 15) and of the Haldager Formation. In the Rønde No. 1 boring the series below the Børglum Member is here determined to belong to the upper member of the Fjerritslev Formation mainly on the basis of the cuttings samples. In the Gassum and Nøvling borings the occurrence of the boundary between the Fjerritslev Formation and the Børglum Member is primarily indicated by the geological age determined by the ostracod faunas (cf. Christensen 1971, 1973, and Michelsen 1971, 1973), which only gives a pseudo-lithostratigraphical determination.

Subdivision. The Fjerritslev Formation can be subdivided into the four members described below. They will be defined formally and named when some new borings are released for publication within a few years, as these are the most descriptive sections known from the basin for this part of the Jurassic sequence.

Geological age. Based on studies of the ostracod faunas the Fjerritslev Formation is referred to the Lower Jurassic (Michelsen 1975). The Trias/Jurassic boundary coincides with the lower formational boundary centrally and southerly in the basin, but to the northeast (in the Børglum and Flyvbjerg borings) the boundary is found within the underlying Gassum Formation. The Lower/Middle Jurassic (Aalenian/Bajocian) boundary coincides with the top of the formation. 


\section{Dansk Nordsø J-1}

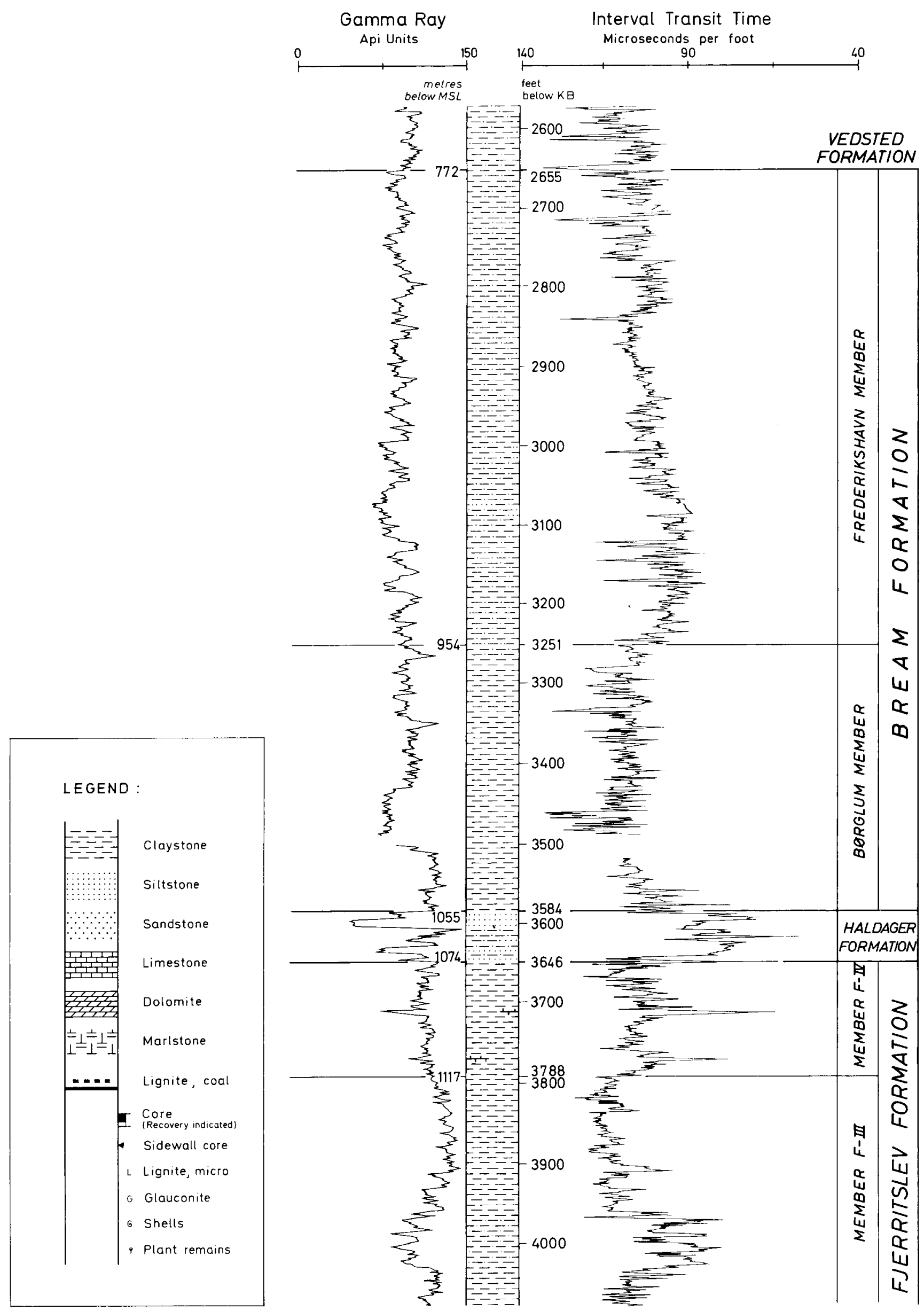

Fig. 5a. 


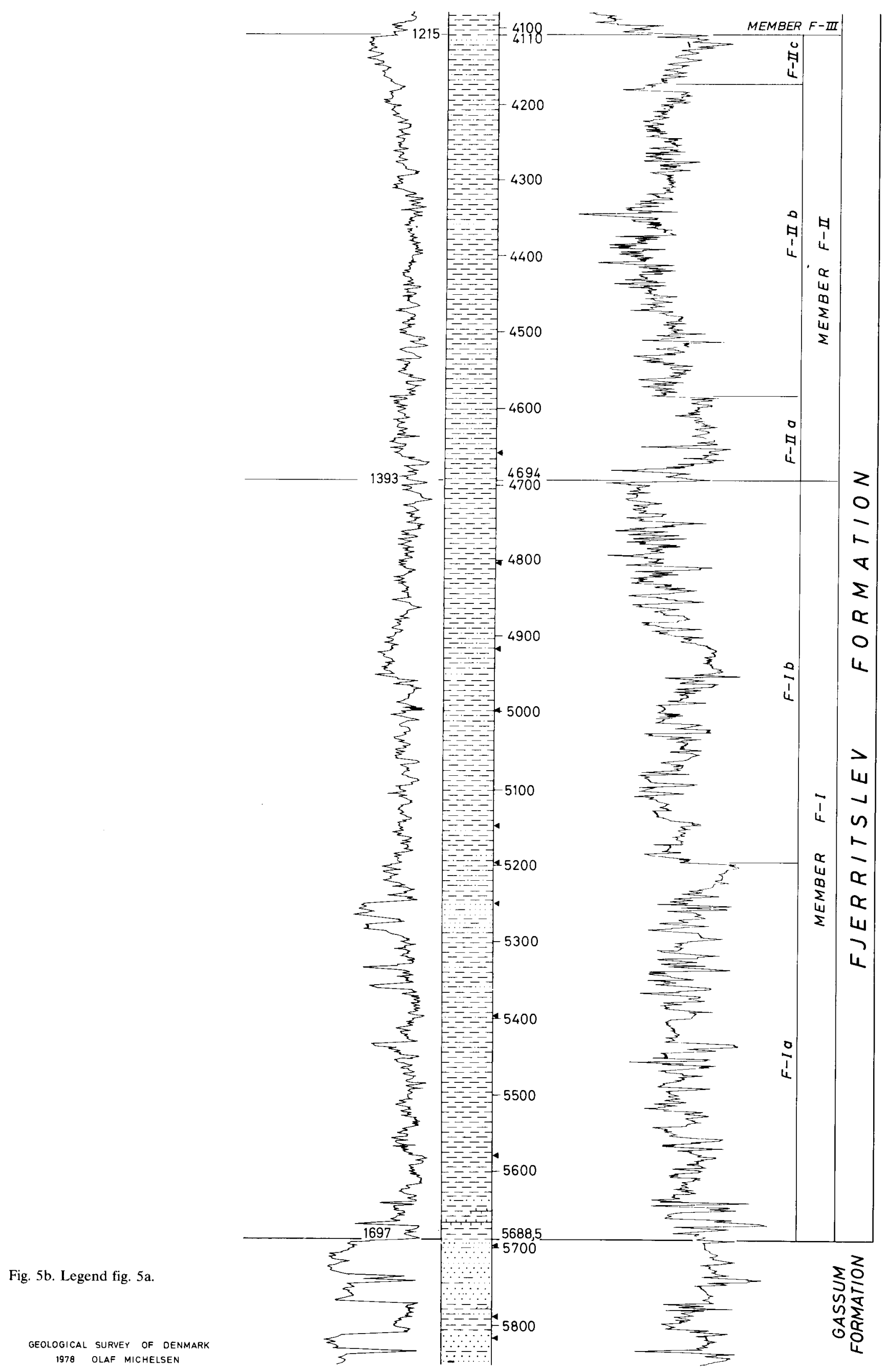


Fjerritslev No. 2

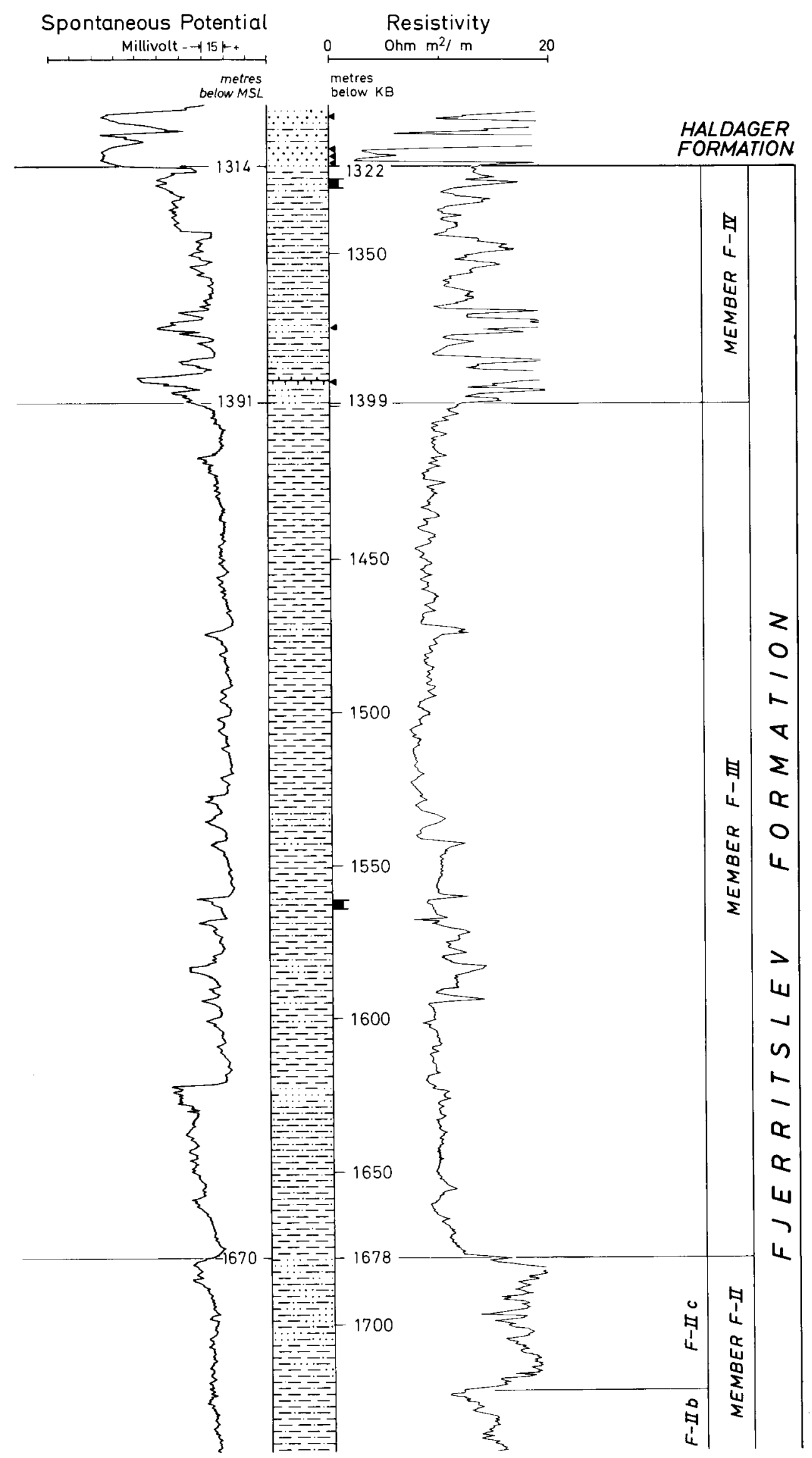




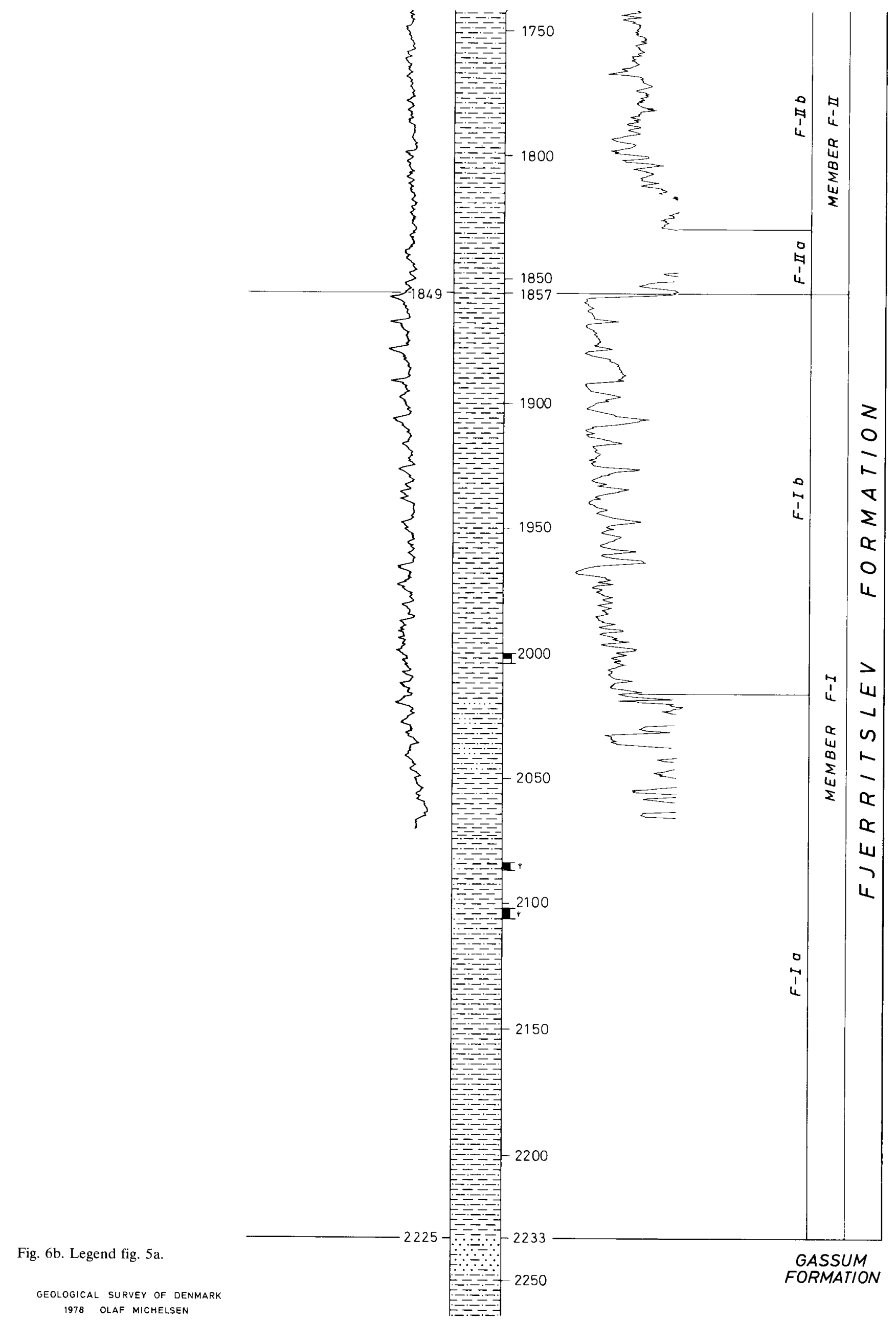




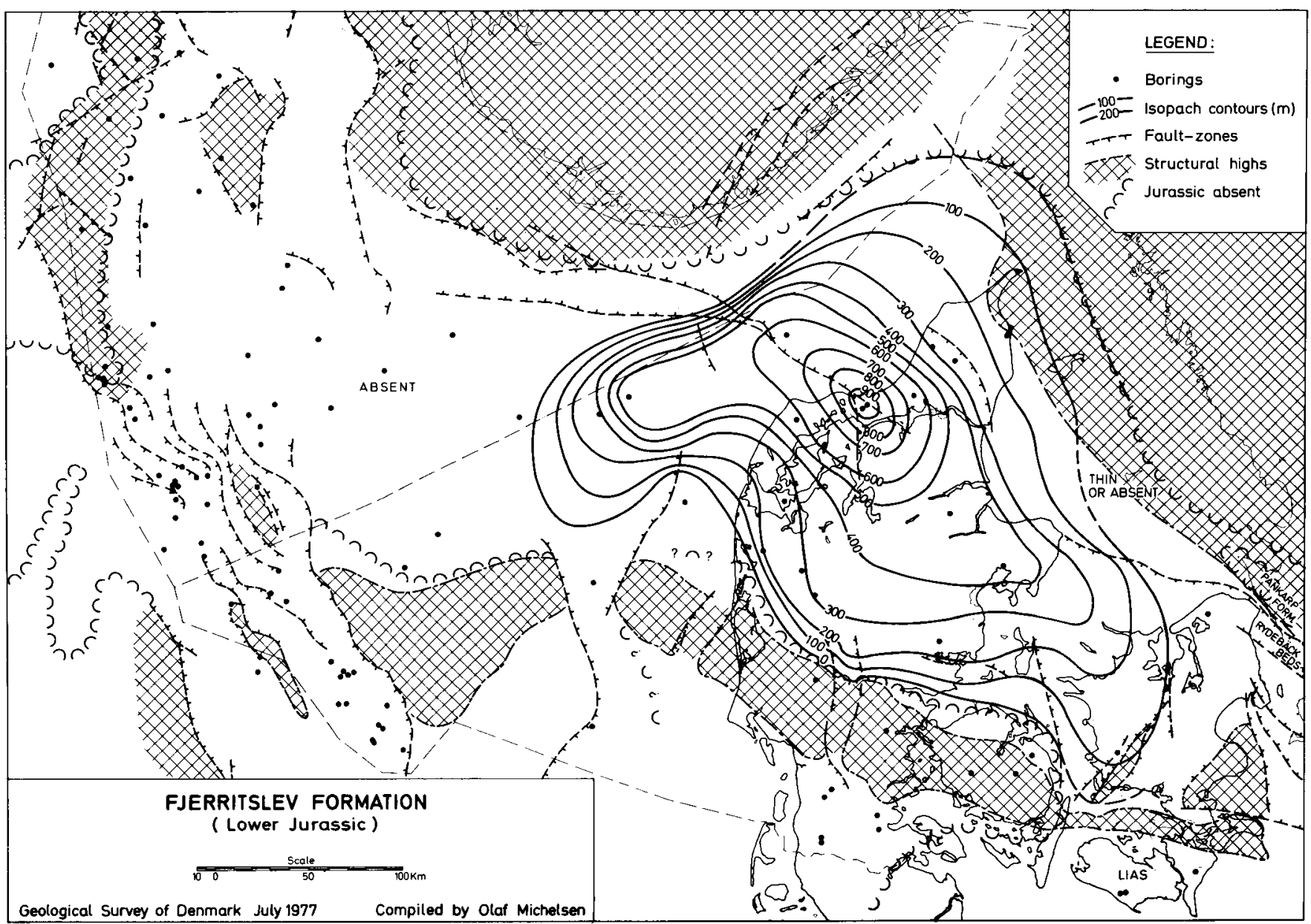

Fig. 7.

Member F-1. (Corresponds to Member I in Michelsen 1976a). Shale with a low silt-content, often noncalcareous, it contains mica, microlignite, and pyrite. The lower part of the member (Ia) represents the transgressive stage with alternating layers of shallow water (siltstone and limestone) and deeper water (shale) sediments. This lower part is characterized by rapidly changing values of the gamma ray and interval transit time curves corresponding to this interbedding (see figs. 5 and 14). The upper part (F-Ib) consists of shale only, as demonstrated by the rather smooth curves.

The fossil content of the lower part shows increasing faunal density and diversity upwards and the shells are well-preserved. In the upper part the faunal diversity and density are remarkably low and the shells are badly preserved, often corroded.

On the basis of the ostracod faunas the member is referred to the Hettangian, Sinemurian, and parts of Lower Pliensbachian (Michelsen 1975). For the depositional period of $\mathrm{F}-\mathrm{Ia}$ the depositional environment is interpreted as shallow-water, well oxidized, and with changing energy levels. In the depositional period of $\mathrm{F}-\mathrm{Ib}$ the water was deeper and reducing conditions prevailed.
Member F-II. (Corresponds to Member II in Michelsen 1976a). Differs from the sections above and below by consisting of a faintly laminated claystone with a relatively high sand and silt content. It contains mica, microlignite, and pyrite. The section is characterized by lower values of the SP, gamma ray, and interval transit time logs (figs. 5, 6, 12, and 14). The upper boundary in particular is distinctly marked by a deflection on the curves. This boundary is mappable by seismic methods.

The member can be subdivided into three sub-units which can be distinguished in several borings. This subdivision, and other features of the wire line logs, indicate that parts of the member (often the upper part) are missing locally. In spite of missing biostratigraphical indications it is assumed that locally there may be a small unconformity at the top of the member. On the basis of the ostracod faunas the member is referred to the upper part of the Lower Pliensbachian and the lowermost Upper Pliensbachian (Michelsen 1975).

The faunal diversity and density is very high and the ostracod shells are well-preserved. The environmental conditions are intepreted as being well oxidi- 
zed and probably shallow-water. Sedimentary indications of shallow-water conditions are found in a few samples.

Member F-III. (Corresponds to lower part of Member III in Michelsen 1976a). Shaly claystone, in places slightly silty, slightly calcareous. Contains mica and microlignite. The section is characterized by relatively high gamma ray and interval transit time values, but more rapidly changing values are found than in the upper part of member F-I (figs. 5 and 14).

The faunal diversity and density are relatively high (though lower than in member F-II), but the shells are often slightly corroded.

The environment is interpreted as being deeper water, upwards with increasingly reducing conditions. - The upper part of the sequence is barren of fossils; the lower part comprises Upper Pliensbachian ostracod faunas (Michelsen 1975).

Member $F-I V$. (Corresponds to upper part of Member III in Michelsen 1976a). The sediments consist of laminated claystone with varying silt content, silt laminae, calcareous, often non-calcareous in the upper part. Layers of cross-bedded sandstone occur. Carbonized plant-remains are common. Shell fragments or pyrite-casts of shells are rather common in certain levels. The gamma ray and interval transit time curves show a characteristic log pattern with marked deflections indicating a rythmic sedimentation of sand and clay. At least two cycles seem to be present (figs. 6 and 15).

The faunas, i.e. Aalenian ostracod faunas, seem to be impoverished or with a very low diversity. The sequence was probably deposited in a lagoonal environment with strongly reducing conditions close to the bottom.

\section{The Fjerritslev/Haldager Formation boundary}

The boundary used here is placed at a different level from the one used earlier by Larsen 1966 (cf. figs. 13 and 15). Earlier the series of member F-IV was included in the Fjerritslev Formation in the Fjerritslev No. 2 boring, in the Haldager Formation in the Haldager No. 1 and Frederikshavn borings, and apportioned between the two formations in the Flyvbjerg No. 1 and Børglum No. 1 borings. The member is here considered to belong to the Fjerritslev Formation for two reasons: 1) It is a marine claystone series closely related to the marine claystone and shale below, but different from the deltaic series above. 2) The unconformity above separates the more or less eroded top of the Fjerritslev Formation from the delta sheet sand of the lower part of the Haldager Formation (fig. 13).

The occurrence of a pronounced unconformity between the two formations is clearly demonstrated by the lithostratigraphical correlation (fig. 13) and by the biostratigraphical determination (cf. Michelsen 1975). To the northeast and in the central part of the basin, Aalenian ostracod faunas are known from the series above the upper, non-fossiliferous part of the member F-III, whereas Upper Pliensbachian ostracod faunas are present just below the unconformity to the southwest (in the Horsens No. 1 and Nøvling No. 1 borings), and Sinemurian faunas occur in the Slagelse No. 1 boring (see fig. 14).

\section{Basinal development}

As mentioned above, the upper part of the Gassum Formation is developed in a near-shore marine facies but with no fossil record. In the central part of the basin the faunas of the lowest part of the Fjerritslev Formation indicate the presence of the lowest Lower Jurassic, whereas fossil records to the northeast (in the Flyvbjerg No. 1 boring, see Michelsen 1975) refer parts of the Gassum Formation to the Lower Jurassic. The transgression with deposition of marine claystone seems to have started centrally or southerly in the basin, and from the ostracod faunas there seems to have been a main communication with the North German Basin.

During the Hettangian and Lower Sinemurian, marine claystone was deposited centrally and southerly in the basin, whereas deltaic and littoral conditions prevailed to the northeast (northern-most Jylland) as well as in the Danish-Polish Trough (the Scanian Helsingborg and Döshult Formations). The main subsidence took place during the Upper Sinemurian and Lower Pliensbachian. The depo-centre moved slightly eastwards from northwest Jylland to the area around the Fjerritslev Fault (see fig. 12). The corresponding members $\mathrm{F}-\mathrm{I}(\mathrm{b})$ and $\mathrm{F}-\mathrm{II}$ are contemporary with the Scanian Pankarp and Kattlösa Formations respectively. Deposition of member F-III took place during the Upper Pliensbachian and Toarcian (Michelsen 1975 and 1976a), and at the same time the depo-centre moved to the east of the Fjerritslev Fault. During the Aalenian, lagoonal conditions prevailed, probably owing to a relative lowering of the sea level. The depo-centre seems to have moved further eastwards (fig. 13).

The subsequent erosion of the Lower Jurassic sequence along the Ringkøbing-Fyn High, to the 
southeast (Sjælland), and probably to the northwest (in the Norwegian part of the basin) is supposed to be due to tectonic elevation of these areas. Fault activities are recognized elsewhere in the North Sea area at the end of the Lower Jurassic, and a disconformity is found between Lower and Middle Jurassic (Rønnevik et al. 1975). In the Central Trough, too, the upper part of the Lower Jurassic is missing (Michelsen 1976b). Neither lithological nor biological indications of near-shore conditions are found in these areas. Therefore the Ringkøbing-Fyn High is not regarded as a source area as mentioned by several authors. The closely related rhythm in sedimentation between the East Shetland Basin and the Norwegian-Danish Basin make it reasonable to assume that sedimentation has taken place within one large region under the same eustatic control, followed by elevation and erosion at the end of the Lower Jurassic (cf. Younge et al. 1975 , fig. 7 and fig. 5 in the present paper).

\section{Middle Jurassic}

The period is primarily regressive. Littoral and deltaic conditions prevailed in large parts of the North Sea region (Al Kasim et al. 1975, Brooks et al. 1975). Preliminary palynological studies on Danish material carried out by Finn Bertelsen (Geological Survey of Denmark) refer the deltaic series to the Middle Jurassic, while Oxfordian ostracod faunas have been found in the overlying series by Christensen (1974) and the present author.

\section{Haldager Formation \\ Emended}

History. The formation was described by Larsen (1966, pp. 34-35), but without a distinct definition of the boundaries. Revision of the lower boundary is discussed p. 15.

Type locality. The Haldager No. 1 boring, 1068-1275 m b. MSL. (see fig. 8).

Reference section. The Vedsted No. 1 boring, 1119-1219 m b. MSL. (see fig. 8).

Thickness and distribution. The maximum thickness $(207 \mathrm{~m})$ is found in the type section, which is located in the southeastern part of the area having the greatest average thickness (see fig. 9). The formation or equivalent deposits may be present in the western part of the basin (see Deegan \& Scull 1977, figs. 25 and 26).

Lithology. The sediments included in the formation are separated from those above and below as arrenaceous, deltaic and near-shore deposits. The lower part consists of sandstone to coarse-grained siltstone, carbonized plant-remains and coal, interbedded by thin beds of black, non-calcareous claystone. The upper part consists of marine, silty claystone, with beds of sandstone and limestone.

Boundaries. The lower boundary is described and discussed on pp. 9 and 15.

The upper boundary is placed at the top of the uppermost sand- or siltstone bed, in the type section determined by the SP and resistivity logs. To the northeast, in the Flyvbjerg No. 1 and Frederikshavn No. 1 borings, this bed is thicker and more significant. To the southwest the series thins out and correlation per bed is difficult, but the gamma ray log shows upwardly decreasing values, with high values lowermost in the overlying Børglum Member. The SP $\log$ reflects the same sedimentary characters.

Subdivision. The formation can be subdivided into two members which are defined below.

Geological age. Palynological studies and analyses of the ostracod faunas refer the formation to Middle Jurassic and lowermost Upper Jurassic (for further information see the two members).

\section{Haldager Sand}

New member

History. Described in Michelsen (1977) as Member $\mathrm{H}-\mathrm{I}$.

Type locality. The Haldager No. 1 boring, 1120-1275 m b. MSL. (see fig. 8).

Reference section. The Vedsted No. 1 boring, 1144-1219 m b. MSL. (see fig. 8).

Thickness and distribution. The maximum thickness $(154 \mathrm{~m})$ is found in the type section. The thickness relative to the distribution conforms to that of the formation (see figs. 9 and 15).

Lithology. The series consists of fine to medium-grained sandstone and siltstone, often homogenous and well-sorted, light olive-grey, non-calcareous, with mica, microlignite, carbonized plant-remains, 


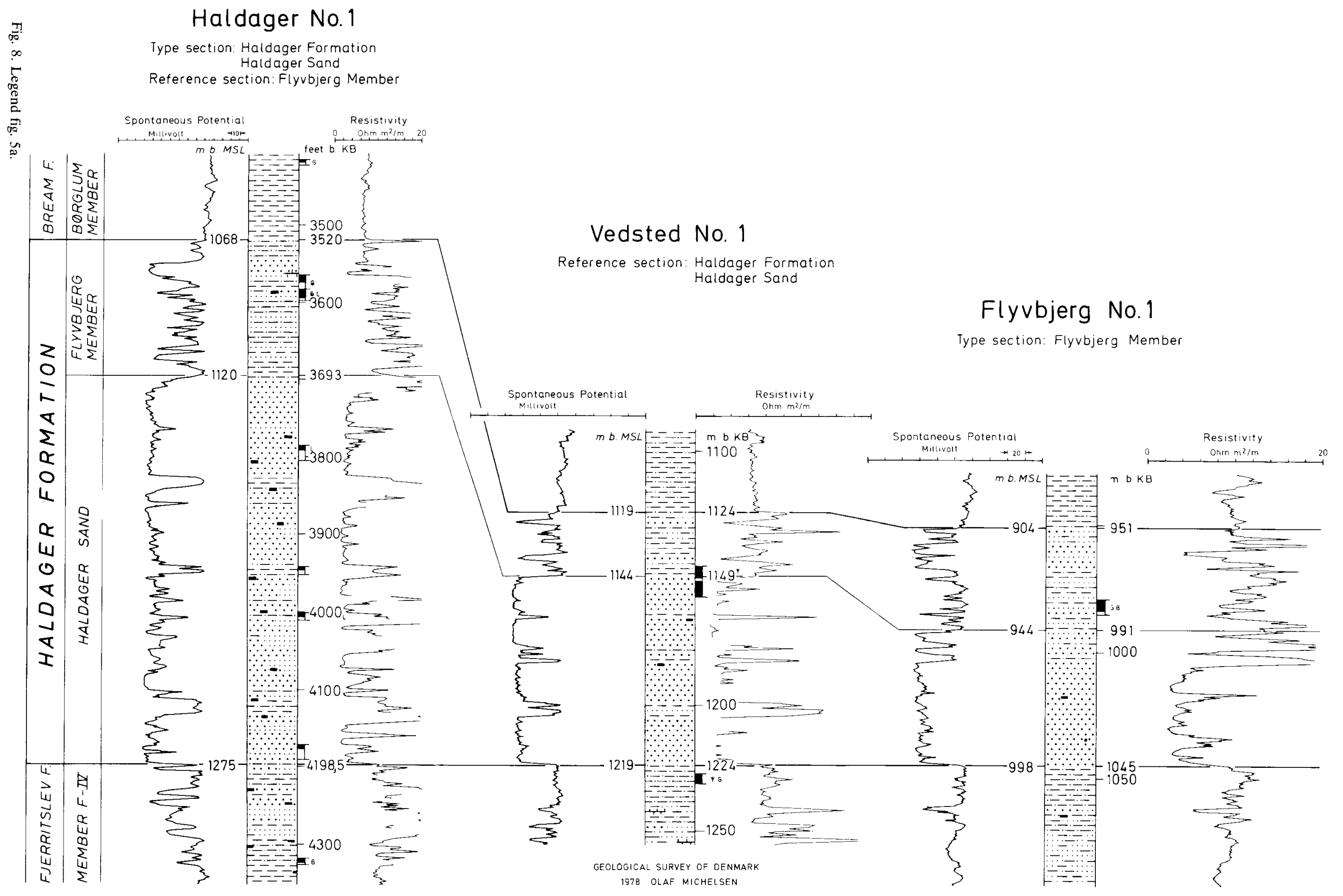




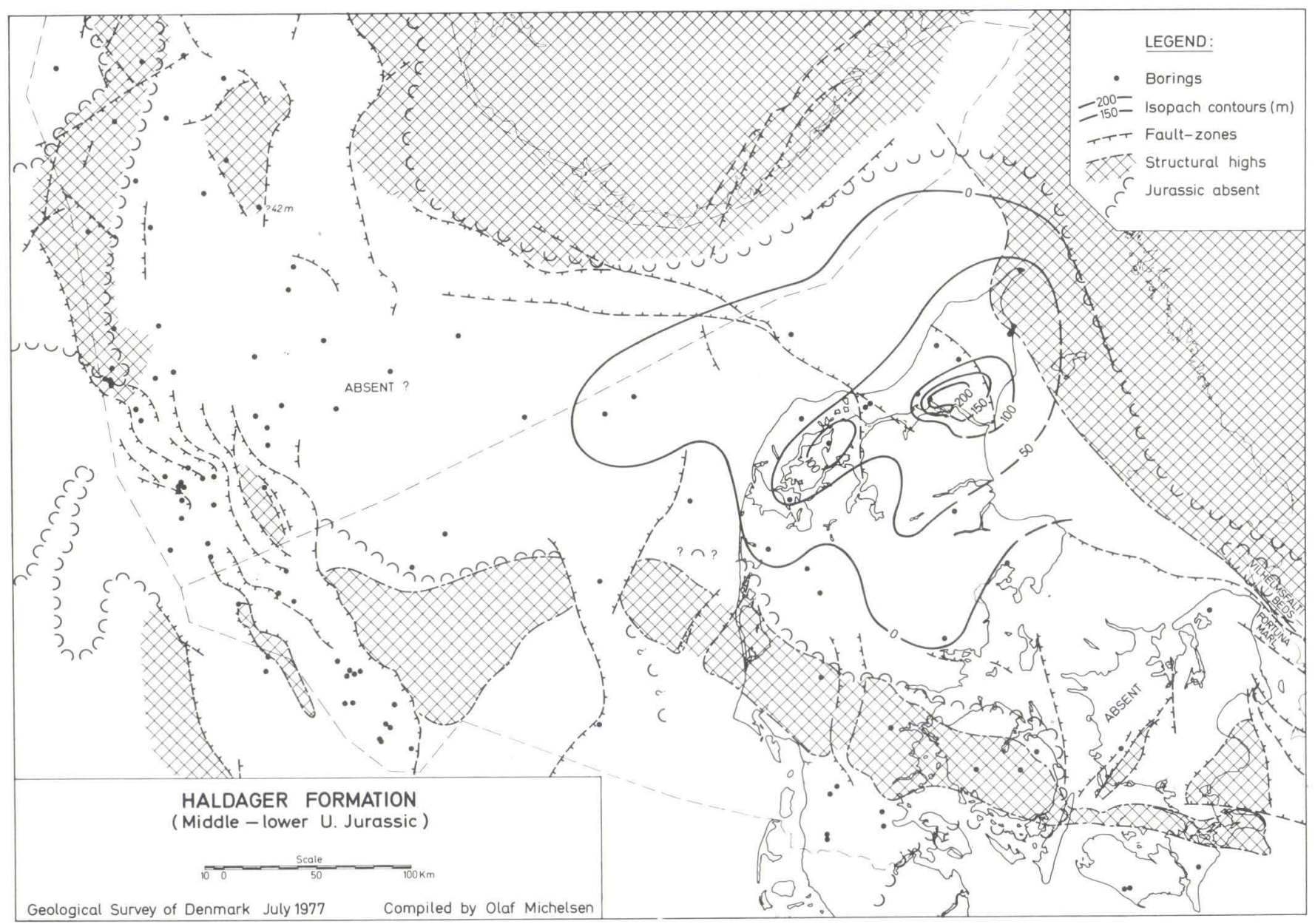

Fig. 9.

and coal. Interbedded with thin beds of grey to black, sandy, and non-calcareous claystone. No marine indications. Cross-bedding is observed. More centrally in the basin where the series is thinner local variations occur: from well-sorted sand- or siltstone with thin clay laminae to badly sorted, clayey, and sandy siltstone without lignite and coal.

In the type section the pattern of the SP and gamma ray logs shows six series of sand deposits. In the lower three series the log pattern indicates upwardly increasing grain size and in the upper two upwardly decreasing grain size. In other borings fewer series (or cycles) are found making a bed by bed correlation difficult. The series is interpreted as being a deltaic deposition succeeded by infillings of interdistributary channels in the upper part of the type section. The latter type of sedimentation may occur in the main part of the area to the southwest.

Boundaries. The lower boundary is described and discussed on pp. 9 and 15 .

The upper boundary is defined as the top of the massive sand beds. Generally the gamma ray and interval transit time curves show very low values for the
Haldager Sand, corresponding to the thick series of clean sand deposits. These sedimentary characters are also reflected by the SP $\log$ and by the simultaneous compensated neutron formation density log. These wire line logs determine the lower and upper boundaries clearly.

Geological age. Middle Jurassic age is indicated by preliminary palynological studies of a few borings carried out by Finn Bertelsen (Geological Survey of Denmark).

\section{Flyvbjerg Member}

New member

History. Described in Michelsen (1977) as Member H-II.

Type locality. The Flyvbjerg No. 1 boring, 904-944 m b. MSL. (see fig. 8). 
Reference sections. The Haldager No. 1 boring, 1068-1120 m b. MSL.; the Frederikshavn No. 1 boring, 636-689 $\mathrm{m} \mathrm{b}$. MSL. (see figs. 8 and 10).

Thickness and distribution. The maximum thicknesses $(53$ and $52 \mathrm{~m})$ are found in the Haldager No. 1 and Frederikshavn No. 1 borings respectively. For distribution see fig. 15. The Egersund Member may be an equivalent deposition in the western part of the basin (see Deegan \& Scull 1977, fig. 25).

Lithology. Uppermost is found sandstone, homogenous, fine-grained, well-sorted, strongly calcareous, with glauconite and traces of pyrite.

Below follows a bedded series of:

Claystone, olive-grey, shaly, strongly calcareous, with microlignite, and shell fragments (pyritizised fossils). - Claystone, sandy, shaly, greenish black, poorly sorted, calcareous, with microlignite, pyrite, and trace-fossils. - Claystone-siltstone, laminated, greyish to olive-black, interbedded with siltstone, slightly calcareous, with traces of microlignite and glauconite. - Sandstone, fine-grained, non-calcareous. - Limestone beds occur uppermost in this part of the series to the northeast in the basin.

Lowermost is found sandstone and siltstone, slightly laminated, poorly sorted, light olive-grey, non-calcareous, with mica and pyrite, traces of coal and lignite. This is interbedded with claystone, more or less silty, greyish black, non-calcareous, with mica and microlignite.

This sedimentary sequence comprises rapidly changing facies. The environment of deposition is interpreted as non-marine lowermost, passing upwards into marine, shallow-water conditions with changing energy levels, which may represent an interdistributary bay to tidal flat environment.

Boundaries. The upper and lower boundaries are described pp. 16 and 18 respectively. The delimitation with the massive sand beds below and the uniform claystone series above is clear in most of the borings. However, in the three North Sea borings, $\mathrm{F}-1, \mathrm{~J}-1$ and $\mathrm{K}-1$, a definite determination of the two members is more difficult.

Geological age. Oxfordian age is indicated by ostracod faunas in parts of the series (cf. Christensen 1974).

\section{Basinal development}

After elevation of the southern, southeastern, and western parts of the basin, and subsequent erosion at the end of the Lower Jurassic, sand blankets were deposited in a transitional marine environment (the Haldager Sand) with a depo-centre in the north of Jylland, east of the Fjerritslev Fault (see fig. 15). The sand deposits may have been deposited as delta front layers or in parts of the basin as infilling of interdistributary channels. The area of greater thickness around the Mors No. 1 boring (see fig. 15) is assumed to be due to a depression bordering a salt dome.

Corresponding deposits have not yet been published from the Norwegian part of the basin (see the description of the Gassum Formation). Deposits of Middle and Upper Jurassic age are missing to the southeast (on Sjælland) where Lower Cretaceous sediments rest directly on the Lower Jurassic. To the east or southeast in the Danish-Polish Trough, corresponding series of probably Bajocian and Bathonian age are found in Scania and on Bornholm (Tralau 1966). The formation of these clastic wedges is suggested to reflect faulting along the basin margin and rejuvenation of the source areas to the east and northeast, resulting in depositional regression (see also Rolle et al. 1977). The great difference in thickness, from 4 and $9 \mathrm{~m}$ in the Horsens No. 1 and Vemb No. 1 borings respectively to more than $150 \mathrm{~m}$ in the Haldager No. 1 boring and c. $40 \mathrm{~m}$ in the Frederikshavn borings, indicates a source area to the northeast. The Ringkøbing-Fyn High has probably not been a source area as suggested by several authors.

The Middle-Upper Jurassic transition is determined as lying within the lower part of the shallow marine series uppermost in the Haldager Formation, within the Flyvbjerg Member. Deposits of this character and of the same age may be present in the Norwegian Egersund Member. Corresponding sedimentation has been described from the East Shetland Basin, the Moray Firth Basin, and the central part of the North Sea (Brooks et al. 1975). In Scania, in the Danish-Polish Trough, the marine Fortuna Marl occurs, dated to Bathonian/Callovian, Callovian/Oxfordian, and Oxfordian age (Norling 1972). Comprising a conglomerate lowermost, the Fortuna Marl covers the Bathonian Glass Sand, which was deposited in a beach foreshore environment (Rolle et al. 1977). Transgression and communication during the Callovian was probably from the south through the Danish-Polish Trough. Deposition of the upper, marine part of the Haldager Formation, the Flyvbjerg Member, probably took place in the Callovian and Oxfordian as the results of a general subsidence and transgression of the area, as known from other parts of the North Sea (Ziegler 1975). 


\section{Upper Jurassic}

Marine offshore and near-shore conditions prevailed in the Upper Jurassic. Upper Jurassic sediments are known only from Jylland and from the areas to the west in the North Sea. Overlying the Oxfordian sediments (the Flyvbjerg Member) are found marine claystone described as the Børglum Member, and marine sand- and siltstone described as the Frederikshavn Member, both included in the Bream Formation.

\section{Bream Formation \\ Emended}

History. The formation was described in Deegan \& Scull (1977, p. 22) as comprising the Egersund Member, the Børglum Member, and the Frederikshavn Member. Michelsen (1976a and 1977) described the same sequence as Formation " $X$ ", comprising the Børglum Member and the Frederikshavn Member. The formation is here re-defined, for the reasons mentioned on p. 4.

Type locality. Norwegian well 9/4-1, 2047-2288 m b. KB. (Deegan \& Scull 1977, p. 22, fig. 25).

Reference sections. The Dansk Nordsø J-1 boring, $772-1055 \mathrm{~m}$ b. MSL., the Børglum No. 1 boring, 733-990 m b. MSL., and the Frederikshavn No. 1 boring, 495-636 m b. MSL. (see figs. 5 and 10).

Thickness and distribution. The maximum thicknesses in the Danish Subbasin (283 and $288 \mathrm{~m}$ ) are observed in the Dansk Nordsø J-1, Vedsted No. 1 and Haldager No. 1 borings respectively. In the Egersund Subbasin the thickness seems to exceed $400 \mathrm{~m}$. Concerning distribution and relative thickness see fig. 11 .

Lithology. In the lower part marine claystone, in places slightly silty, dark coloured, slightly calcareous. To the west, in the Egersund Subbasin, this part of the formation is rich in organic material and highly radioactive.

The upper part of the formation consists of siltstone, fine-grained sandstone, and silty claystone with limestone layers of a near-shore environment. The sediments at the eastern margin of the basin are rather coarse-grained and contain lignite; thin coal beds may occur. They become more fine-grained towards the centre of the basin.
Boundaries. The lower boundary is defined by the contact of the Børglum Member with the Flyvbjerg Member in the Danish Subbasin and that of the Børglum Member with the Egersund Member in the Egersund Subbasin. The former contact is described p. 16. The latter contact is described in Deegan \& Scull (1977, p. 22, fig. 25): "The shales of the Børglum Member have a high radioactivity and a low velocity (compare the Kimmeridge Clay Formation), and therefore the upper boundary of the Egersund Member is marked by strong log breaks".

The upper boundary is the top of the predominantly silty and sandy Frederikshavn Member which is overlain by the shaly Valhall Formation in the Egersund Subbasin (described in Deegan \& Scull, 1977, p. 22, fig. 25). In the Danish Subbasin the Frederikshavn Member is overlain by the shaly Vedsted Formation. At the northeastern margin of the subbasin the boundary is clearly marked by a break in the SP and resistivity logs (figs. 10 and 16). Towards the centre of the basin, to the west, there is a less pronounced contrast as described below (p. 23).

Subdivision. The formation is subdivided into a shaly unit and a silty to sandy unit: The Børglum Member and the Frederikshavn Member. The third member mentioned in Deegan \& Scull (1977), the Egersund Member is here considered as being equivalent to the Flyvbjerg Member.

Geological age. Kimmeridgian to lowermost Lower Cretaceous according to studies of the ostracod faunas (Christensen 1974 and the present author) and to studies of the dinocysts (Davey 1976).

\section{Børglum Member}

Emended

History. This member was described as the Børglum Formation by Larsen (1966, p. 36). Michelsen (1976, p. 111) pointed out the difficulties in separating it from the overlaying Frederikshavn Member and subordinated these two members to a new formation. New wire line logs, belonging to not yet released borings, are the basis for moving the upper part of the former Børglum Formation to the lower part of the Frederikshavn Member.

Type locality. The Børglum No. 1 boring, 957-990 m b. MSL. (see fig. 10).

Reference sections. The Frederikshavn No. 1 boring, 629-636 m b. MSL.; the Dansk Nordsø J-1 boring, 954-1055 m b. MSL. (see figs. 10 and 5). 


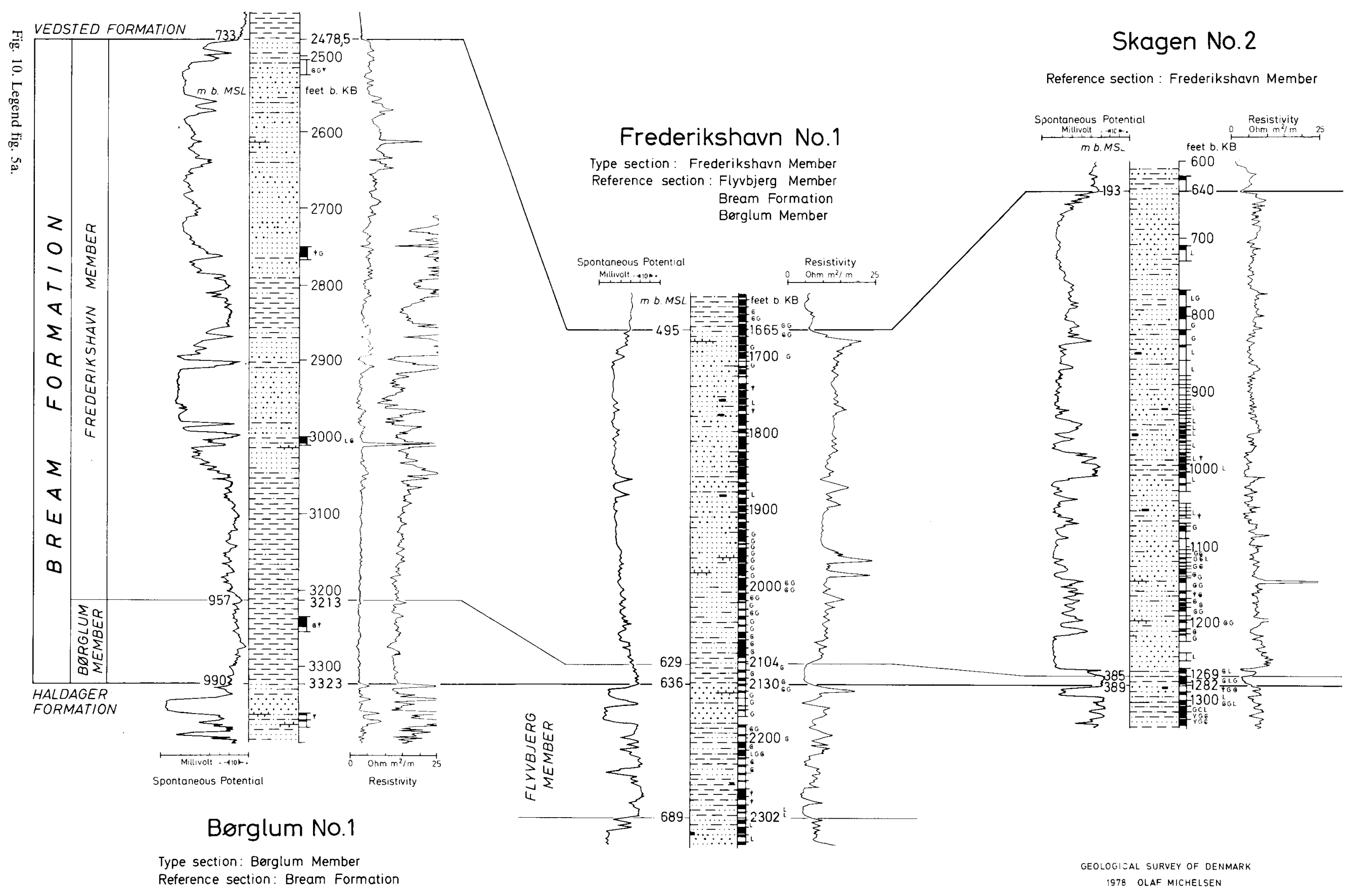




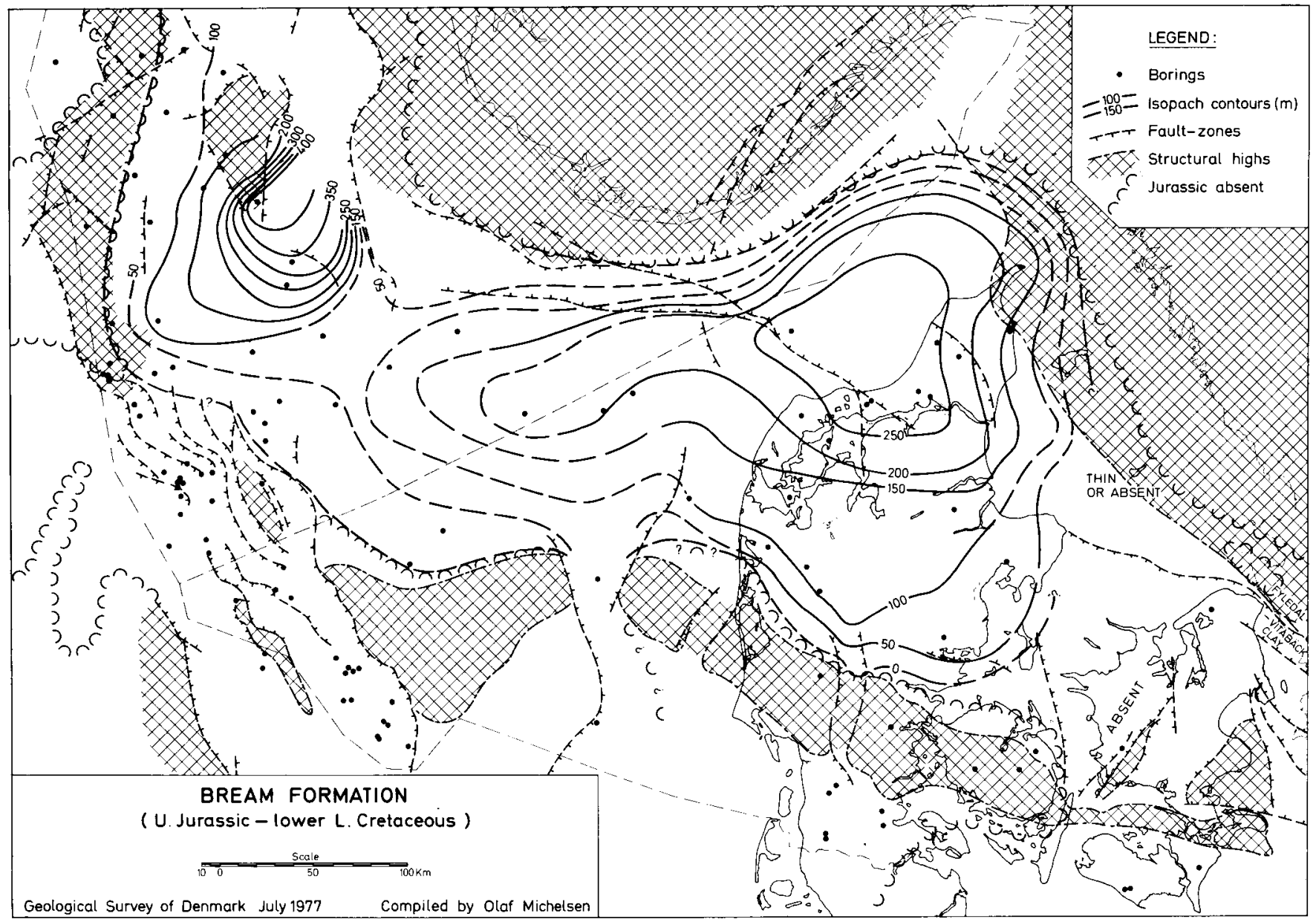

Fig. 11.

Thickness and distribution. The maximum thicknesses $(123,113$, and $101 \mathrm{~m})$ are found in the Mors No. 1, Fjerritslev No. 2, and Dansk Nordsø J-1 borings respectively (see fig. 16). The member seems to occur in the entire Norwegian-Danish Basin, and even with a pronounced thickness in the Egersund Subba$\sin$ (cf. NPD paper No. 1, 1975).

Lithology. Shaly claystone, homogenous, often slightly silty, olive-grey to blackish grey, slightly calcareous to non-calcareous, with mica, pyrite, shell fragments, traces of microlignite, and ? trace-fossils.

The SP $\log$ and high values of the gamma ray and interval transit time curves indicate a uniform claystone series. Furthest to the northwest the pattern of the logs seems to change character and very high gamma ray values are found, at least in the lower part of series (cf. NPD paper Nos. 4 and 11).

Boundaries. The lower boundary is described on p. 20 .

A more or less even transition is seen in the sediments near the boundary between the Børglum Member and the Frederikshavn Member, passing from claystone to silty claystone. The boundary may be defined on the gamma ray log by determining a clay/silt boundary level. However, the interval transit time log is the most significant log for this boundary. The characteristic change to lower values in the Frederikshavn Member, as seen in the Dansk Nordsø $\mathrm{J}-1$ boring (fig. 5), is found in the most of the recent borings (cf. fig. 17) and is used for definition of the boundary. The correlation to older borings is done by means of the SP and resistivity logs which have been run in nearly all borings.

Subdivision. The member is not formally subdivided into subunits, but a difference in the characters of the upper and lower parts must be mentioned. As seen in the Rønde No. 1 boring (fig. 17) and the Dansk Nordsø J-1 boring (fig. 5) the gamma ray log shows an upwardly decreasing grain-size. The interval transit time curve shows a subdivision with a uniform lower part and an upper part with pronounced deflections. A sedimentological definition has not yet been given. 
Geological age. The sequence is referred to the Kimmeridgian and the lower part of the Portlandian on the basis of the ostracod faunas (Christensen 1974 and the present author).

\section{Frederikshavn Member \\ Emended}

History. The member was described as the Frederikshavn Formation and the Skagen Formation by Larsen (1966, pp. 38-40), who considered the first-named formation as "a marine border facies" and the last one as "a deltaic product".

Michelsen (1977) proposed that the two formations be included as one member, the Frederikshavn Member, since they "can hardly be separated". The present Frederikshavn Member comprises the two former formations, which represent a series of near-shore depositions. The subdivision mentioned below does not conform to the former formational boundary.

Type locality. The Frederikshavn No. 1 boring, 495-629 m b. MSL. (see fig. 10).

Reference sections. The Skagen No. 2, 193-385 m b. MSL.; the Dansk Nordsø J-1, 772-954 m b. MSL.; the Børglum No. 1 boring, 733-957 m b. MSL. (see figs. 10 and 5).

Thickness and distribution. The maximum thicknesses (243 and $235 \mathrm{~m})$ are found in the Haldager No. 1 and Vedsted No. 1 borings respectively. In the Egersund Subbasin a series up to $310 \mathrm{~m}$ thick seems to be present (cf. fig. 16). The total distribution of the member in the western part of the basin has not yet been published.

Lithology. Siltstone and fine-grained sandstone, slightly laminated, massive to slightly shaly, greenish grey, light olive-grey, olive-black, slightly calcareous to non-calcareous. In places with mica, pyrite, microlignite, glauconite, and shell fragments. Interbedded with thin beds of claystone, shaly, silty, greyish black, calcareous, with mica, microlignite, and shells.

The upper part of the series includes a well-sorted sandstone. Glauconite and shell fragments are found uppermost and in the lower half of the series.

To the northeast, coal-beds a few $\mathrm{cm}$ thick are found in the upper part of the series.

Thin limestone beds occur locally uppermost and in the lower half of the series.

The SP $\log$ and the low values of the gamma ray and interval transit time logs show a series dominated by siltstone, but without sharp boundaries to the intercalations of claystone and sandstone beds. A rythmic pattern of the gamma ray curve is the basis for distinguishing three cycles, which can also be seen on the SP $\log$ (see fig. 16).

Boundaries. The lower boundary is discussed as the boundary between the Børglum and Frederikshavn Members p. 22.

The upper boundary shows the same characters illustrated by the wire line logs as mentioned for the lower boundary. The upper boundary is also defined on the basis of the interval transit time log and on the gamma ray log by determining a clay/silt level.

Subdivision. As mentioned above, the member is subdivided into three upwardly coarsening sedimentary cycles. The fine-grained (claystone) part of the upper cycle (C) represents a pronounced subsidence of the basin. Increasing thickness of the claystone series is found centrally in the Danish Subbasin (see the Fjerritslev No. 2 and Vedsted No. 1, fig. 16).

Geological age. On the basis of biostratigraphical studies the series is referred to the Kimmeridgian, Portlandian, and lowermost Lower Cretaceous (cf. Christensen 1974). According to studies of dinocysts by Davey (1976) the Jurassic/Cretaceous boundary is placed at the base of the upper cycle (cycle C) in the Haldager No. 1 boring, which corresponds to the boundary between Portlandian and Reightonian in Christensen (1974, p. 111). This determination of the chronostratigraphical boundary is used in the present paper. When correlated from the central part of the Danish Subbasin this chronostratigraphical boundary seems to be situated above the Frederikshavn Member in the sections to the west (i.e. in the Dansk Nordsø J-1 and the Norwegian 9/8-1 borings). Whether the upper cycle is present in these borings cannot yet be determined. If not, the near-shore sandy series of cycle $\mathrm{C}$ may wedge out to the west and the claystone series of the cycle may represent an intercalation of the overlaying Vedsted Formation.

\section{Basinal development}

Above the deltaic and littoral sediments in the lower member of the Haldager Formation, marine shallow-water sediments of Oxfordian and probably Callovian age were deposited. They are overlain by deeper water sediments of Kimmeridgian age. At the 
beginning of the period communication seems to have been with the Mid-European region. At the end of the Lower Kimmeridgian an effective faunal barrier came into existence between the area of deposition in north Jylland and those in Scania and Mid-Europe. The barrier continued to exist in the upper Kimmeridgian and connection was established with the North Sea region (Christensen 1974). In extreme north Jylland shallow-water and near-shore conditions prevailed in the main part of the Upper Jurassic. At the end of the Upper Kimmeridgian and in the Portlandian these environmental conditions covered the Danish part of the basin. The amount of coarse-grained material and the grain-size decrease from east to west. The frequences of glauconite and shell fragments seem to increase in the same direction. Faunal compositions indicate communication with the Scanian region during the Portlandian. A short marine transgression with deposition of more fine-grained sediments is found at the base of cycle $\mathrm{C}$ of the Frederikshavn Member, i.e. at the Juras$\mathrm{sic} /$ Cretaceous transition (in the Ryazanian).

In the Upper Jurassic the depo-centre is still found at or east of the Fjerritslev Fault. However, during this period the subsidence of the western part of the basin is evident (see fig. 16). Especially in the Egersund Subbasin very thick series of sediments are found.

The known tectonic movements (cf. Ziegler 1975) do not markedly influence sedimentation in the Norwegian-Danish Basin during the Upper Jurassic. A small unconformity seems to occur at the base of the Børglum Formation. Locally the upper member of the underlying Haldager Formation is missing. In the Danish part of the basin there is an even transition from the offshore Børglum Member to the near-shore Frederikshavn Member and to the overlying offshore Vedsted Formation of Lower Cretaceous age. The thick series of the Frederikshavn Member in eastern Jylland, known from the Skagen No. 2 boring in the north to the Horsens No. 1 boring in the south, may indicate the position of the coast. The uppermost part of the near-shore sediments, cycle $\mathrm{C}$, is probably absent to the west in the Dansk Nordsø J-1 and the Norwegian 9/8-1 borings, where there seems to be a continuous sedimentation of offshore marine claystone passing the Jurassic/Cretaceous boundary. However, farthest west, on the edge of the Utsira High, Portlandian sediments are absent in the Norwegian 16/6-1 boring (NPD paper No. 9).

\section{Summary}

The Lower Jurassic sediments (the Fjerritslev Formation) are restricted to the eastern part of the basin, east of the Lista Nose. The oldest Lower Jurassic marine offshore sediments are found in central Jylland, whereas deltaic and littoral conditions still prevailed to the north in Jylland, passing the Trias$\mathrm{sic} / \mathrm{Jurassic}$ boundary, as well as in the East Shetland Basin, the Central Trough, and the Danish-Polish Trough. Marine communication with north Germany is indicated by the fossils. Lower Jurassic sediments are absent in the western part of the basin, probably due to uplift of the area and erosion at the end of Lower Jurassic.

The Middle Jurassic deltaic and shallow water sediments of the Haldager Formation also seem to be restricted to the area east of Lista Nose. A pronounced unconformity is found at the base of this series.

Upper Jurassic sediments (the Bream Formation) cover the entire basin, but with concentration on two depo-centres separated by the Lista Nose - one in the Danish Subbasin and one in the Egersund Subbasin (see fig. 16). In the eastern depo-centre, the Late Kimmerian movements are indicated by intercalation of near-shore and offshore sedimentation; in the extreme west by an unconformity as known from the Central Trough.

The structural feature of Lista Nose forms an important element in Jurassic history. During the Lower and Middle Jurassic it divides the basin into the Danish Subbasin and the western part showing positive features. During the upper Jurassic there seems to be differences in the structural function and probably also in function of sedimentation. The Norwegian $9 / 8-1$ boring is the only one of the borings published from that area to which correlation can be made using lithostratigraphical evidence. However, the great difference between the upper Jurassic claystone of the Central Trough and of the Norwegian-Danish Basin, described by Fuller (1975), indicates a Central Trough facies and a Norwegian-Danish Basin facies. 


\section{Acknowledgements}

I wish to express my sincere thanks to dr.phil. Leif Banke Rasmussen, head of the Department of Subsurface Geology, cand.scient. Finn Bertelsen, and cand.scient. Søren Priisholm for helpful discussions and suggestions; and to Jens Christian Olsen for assistance in compiling the figures. Mrs. Vibeke Hermansen typed the fair copy of the manuscript; mrs. Kirsten Andersen and Helle Zetterval produced the drawings; and cand.scient. Mike Robson corrected my English manuscript.

\section{Dansk sammendrag}

\section{Stratigrafi og udbredelse af jura aflejringerne i det Norsk-danske Bassin}

Den lithostratigrafiske inddeling, udbredelsen og tykkelsen af de jurassiske aflejringer $i$ det Norsk-danske Bassin er beskrevet i nærværende afhandling. Larsen (1966) foretog den første lithostratigrafiske inddeling med definitionen af fem formationer: Fjerritslev, Haldager, Børglum, Frederikshavn og Skagen Formationerne. Michelsen (1976) foreslog Fjerritslev Formationen inddelt i tre members, samt oprettelse af en ny formation (formation X) omfattende et Børglum Member og et Frederikshavn Member. Deegan \& Scull (1977) opstillede en ny formation, Bream Formation, omfattende de nævnte Børglum og Frederikshavn Members. Hverken Michelsen (1976) eller Deegan \& Scull (1977) har taget stilling til forholdet mellem Skagen Formationen og Frederikshavn Formationen.

I nærværende afhandling er der foretaget en revision og redefinition af den eksisterende lithostratigrafiske inddeling, således at der her regnes med tre formationer, der igen underinddeles $\mathrm{i}$ en rakke members (se fig. 3). Den lithostratigrafiske inddeling baseres primært på wire line logs, så som gamma ray, interval transit time, SP, resistivity og simultaneous compensated neutron formation density. Borekærner og side wall cores er sammen med de nævnte logs benyttet ved beskrivelse af sedimenternes sammensætning og karakterer, således som det er givet i den nedenstående, kortfattede oversigt.

Fjerritslev Formationen er en forholdsvis ensartet lagserie af marine lersten, der på grundlag af analyser af ostracodfaunaerne er henført til nedre jura. Formationen er defineret ved lagserien i boringen Fjerritslev nr. 2 (fig. 6). I forhold til tidligere er den nedre grænse placeret lidt højere i lagserien, - ved top af et mindre sandlag. Udbredelse og tykkelse fremgår af fig. 7. Formationen underinddeles i fire, ikke navngivne members, der hver for sig repræsenterer forskellige aflejringsbetingelser. Udbredelse og tykkelse fremgår af fig. 12 og 13.

Haldager Formationen hestår af vekslende lag af sandsten, siltsten og lersten, aflejret under deltaiske og lavtvandede marine betingelser. Formationen er defineret ved lagserien i boringen Haldager nr. 1 (fig. 8). I modsætning til tidligere er den nedre grænse lagt ved basis af de massive sandsten, hvilket er i overensstemmelse med den tidligere og nuværende grænse mellem Fjerritslev og Haldager Formationerne i boringen Fjerritslev nr. 2. De underliggende lag (member F-IV) i Haldager boringen var tidligere indeholdt i Haldager Formationen.

Haldager Formationen underinddeles i to nydefinerede members: Haldager Sand og Flyvbjerg Member (fig. 8). Udbredelse og tykkelse for disse ses af fig. 15, og for formationen som helhed af fig. 9. Palynologiske analyser indicerer en mellem jurassisk alder for det førstnæunte member, medens oxfordien ostracodfaunaer er fundet i Flyvbjerg Member.

Bream Formationen består af marine aflejringer, nederst omfattende en næsten ren lerstensserie, Børglum Member, og øverst en overvejende sand- og siltholdig serie, Frederikshavn Member. De to members svarer til de tidligere omtalte formationer: Børglum Formationen og Frederikshavn + Skagen Formationerne.. På grundlag af nye typer wire line logs placeres grænsen mellem de to members inden for den tidligere Børglum Formation. Baseret på analyser af bl.a. ostracodfaunaerne henføres lagserien til øvre jura (kimmeridgien og portlandien) og nederste nedre kridt. Udbredelse og tykkelse af lagserierne fremgår af fig. $11 \mathrm{og} 16$.

På grundlag af nærværende analyser og den lithostratigrafiske inddeling, samt tidligere publicerede biostratigrafiske undersøgelser (Christensen 1974 og Michelsen 1975) gives der en kortfattet oversigt over basisudviklingen i nedre, mellem og øvre jura. Igangværende studier af sedimentkaraktererne, fysiske og biogene strukturer m.m. forventes at resultere i en mere detaljeret beskrivelse af disse forhold i en kommende publikation. 
FJERRIISLEVY FORMATION

\begin{tabular}{|c|c|c|c|c|}
\hline Boring & $\begin{array}{l}\text { Depth b. KB } \\
\text { (m or feet) }\end{array}$ & $\begin{array}{c}\text { Log } \\
\text { (characterizing) }\end{array}$ & $\begin{array}{l}\text { Depth b.MSL } \\
(\mathrm{m})\end{array}$ & $\begin{array}{l}\text { Ihickise } \\
\text { (m) }\end{array}$ \\
\hline B $\phi \mathrm{rg} 1$ um 1 & $3529-4499^{\circ}$ & $S P / S P+R e s$ & $1053-1349$ & 296 \\
\hline Dansk Nords $\$ F-1$ & $.5896-6817.51$ & $\mathrm{GR}+\mathrm{SP} / \mathrm{GR}(+\mathrm{SP})$ & $1760-2041$ & 281 \\
\hline Dansk Nords $\varnothing \mathrm{J}-1$ & $3646-5688.5^{\prime} \quad 1$ & $\operatorname{ITT}(+\mathrm{GR}) / \mathrm{CR}$ & 1074-1697 & 623 \\
\hline Dansk Nords $₫ \mathbf{k}-1$ & $4659-6510^{\circ}$ & $\mathrm{ITT}+\mathrm{Ca} 1 / \mathrm{ITT}$ & $1383-1947$ & 564 \\
\hline Fjerritslev 2 & $1322-2233 \mathrm{~m}$ & SP+Res/ & $1314-2225$ & 911 \\
\hline F1yvbjerg 1 & $1045-1308 \mathrm{~m}$ & $S P / S P$ & $998-1261$ & 263 \\
\hline rederikshavn 1 & $2417-2973$ & $\mathrm{SP} * \operatorname{Res} / \mathrm{SP}+\operatorname{Res}$ & $724-893$ & 169 \\
\hline Frederikshavn 2 & $2333-2903$ & $\mathrm{SP} * \mathrm{GR} / \mathrm{SP} * \mathrm{GR}$ & $696-869$ & 174 \\
\hline Gassum 1 & $3931-4980^{\prime}$ & GR/GR & $1140-1460$ & 320 \\
\hline Ha ldager 1 & $4198.5-5000^{\prime} \mathrm{TD}$ & $\mathrm{sp} /$ & $1275-1519$ & $>244$ \\
\hline Horsens 1 & $1296-1506 \mathrm{~m}$ & $\mathrm{SP}+\operatorname{Res} / \mathrm{SP}+\operatorname{Res}$ & $1239-1449$ & 210 \\
\hline Mors 1 & $2155-2768.4 \mathrm{~m}$ & GR $(+\mathrm{ITT}) / \mathrm{ITT}$ & $2137-2750$ & 613 \\
\hline Nqviling 1 & $1512-1847 \mathrm{~m}$ & $\mathrm{ITT} / \mathrm{ITT}+\mathrm{N}$ & $1443-1778$ & 335 \\
\hline Rønde 1 & $2138.2-2613.6 \mathrm{~m}$ & n $\mathrm{GR}+\mathrm{ITT} / \mathrm{GR}$ & $2096-2571$ & 4/5 \\
\hline Skagen 2 & $1460^{\circ}$ & SP 1 & ${ }^{443-}$ & \\
\hline Slagelse 1 & $973-1150$ m & $G R+N / G R+N$ & $932-1109$ & 177 \\
\hline Thisted 1 & $636-745,8 \mathrm{~m}$ & $\mathrm{GR} / \mathrm{ITT}(+\mathrm{GR})$ & $600-710$ & 110 \\
\hline \multicolumn{5}{|l|}{ Uglev 1} \\
\hline edsted 1 & $-1897.5 \mathrm{~m}$ & SP+Res/SP+Res & $1219-1892$ & 675 \\
\hline & s-1795m & SP/SP & $1575-1779$ & 20 \\
\hline
\end{tabular}

MEMBER F-ill (FJeRritsLeV formation)

\begin{tabular}{|c|c|c|c|c|}
\hline Boring & $\begin{array}{l}\text { Depth b. KB } \\
\text { (m or feet) }\end{array}$ & $\begin{array}{c}\text { Log } \\
\text { (characterizing) }\end{array}$ & $\begin{array}{l}\text { Depth b.MSL } \\
(m)\end{array}$ & $\begin{array}{c}\text { Thicknes } \\
\text { (m) }\end{array}$ \\
\hline B $\phi \mathbf{r g} 1$ um 1 & $3886.5-42177$ & $S \mathrm{P} / \mathrm{SP}+$ Res & $1162-1263$ & 101 \\
\hline \multicolumn{5}{|l|}{ Dansk Nords $\phi$ F-1 } \\
\hline Dansk Nords J-1 & $3788-4110^{\circ}$ & I TT/GR(+1TT) & $1117-1215$ & 98 \\
\hline Dansk Nords $₫ \mathrm{~K}-1$ & $.4690-4914^{\prime}$ & $\mathrm{GR}+\mathrm{SP} / \mathrm{ITT}+\mathrm{Ca}$ & $1392-1461$ & 68 \\
\hline Fjerritslev 2 & $1399-1678 m$ & $\mathrm{SP} * \operatorname{Res} / \mathrm{SP} * \operatorname{Res}$ & $1391-1670$ & 279 \\
\hline F1yvbjerg 1 & $1096-1184.5 \mathrm{~m}$ & $S P+R e s /(S P+R e s)$ & $1049-1137$ & 89 \\
\hline Frederikshavn 1 & $2492-2668^{\prime}$ & $\mathrm{SP} * \mathrm{Res} / \mathrm{SP}+\mathrm{ReS}$ & $747-800$ & 54 \\
\hline Frederikshavn 2 & $2402-2580^{\circ}$ & $S P+R e s / S P+G R+R e s$ & $5 \quad 717-771$ & 54 \\
\hline Gassum 1 & ? & & & \\
\hline Haldager 1 & 4616.5-5000'TD & SP/ & $1402-1519$ & $>117$ \\
\hline Horsens 1 & ? & & & \\
\hline Mors 1 & $2179.5-2327.3 \mathrm{~m}$ & $\mathrm{GR}+\mathrm{ITT} / \mathrm{GR}$ & $2162-2309$ & 148 \\
\hline Novl ing 1 & $?$ & & & \\
\hline Ronde 1 & $2193.2-2337.7 \mathrm{~m}$ & $\mathrm{~N} / \mathrm{GR}+\mathrm{ITT}$ & $2151-2296$ & 145 \\
\hline Skagen 2 & $1554.5-$ & $S P+\operatorname{Res} /$ & $472-$ & \\
\hline \multicolumn{5}{|l|}{ Slagelse 1} \\
\hline \multicolumn{5}{|l|}{ Thisted 1} \\
\hline $\lg 1$ ev 1 & & & & \\
\hline Vedsted 1 & $1257.5-1475 \mathrm{~m}$ & SP+Res/Res (+SP) & $1252-1470$ & 218 \\
\hline jemb 1 & $1590.5-1627.5 \mathrm{~m}$ & $\mathrm{SP} / \mathrm{SP}+\mathrm{Re} S$ & $1575-1612$ & 3 \\
\hline
\end{tabular}

MEMBER F-I (FJERRITSLEV FORMATIOW)

\begin{tabular}{|c|c|c|c|c|}
\hline Boring & $\begin{array}{l}\text { Deptn } b . \quad \text { B } \\
\text { (n or feet) }\end{array}$ & $\begin{array}{c}\text { Log } \\
\text { (characterizing) }\end{array}$ & $\begin{array}{l}\text { Depth b. isSL } \\
\text { (m) }\end{array}$ & $\begin{array}{l}\text { Thicknes } \\
\text { (in) }\end{array}$ \\
\hline Børglum 2 & $4414-4499^{\circ}$ & $\operatorname{Res} / \mathrm{SP} \bullet \operatorname{Res}$ & $1323-1349$ & 26 \\
\hline Wansk Nordss F-1 & $0155-6817.5^{\prime}$ & $\mathrm{GR}+\mathrm{ITT} / \mathrm{CR}(+5 \mathrm{SP})$ & $1839-2041$ & 202 \\
\hline Wansk Nords $\mathrm{J}-1$ & $4694-5688.51$ & ITT + GR/GR & 1393-1697 & 304 \\
\hline Lansk Nordsp $k=1$ & $5162-6510^{\circ}$ & ITT+Res/ITT & $1530-1947$ & 411 \\
\hline Herritslev 2 & $1857-2233 m$ & Res/ & $1849-2225$ & 370 \\
\hline Flyvbjerg 1 & $1272-1303 \mathrm{~m}$ & $S p+R e s / S P$ & $1225-1261$ & 36 \\
\hline Frederikshavn 1 & $2932-2973^{\circ}$ & Res $\$$ SP $/$ Res $* S P$ & $881-893$ & 12 \\
\hline Frederikshavn 2 & $2850-29031$ & $S P(+R \in S) / S P+G R$ & $855-869$ & 14 \\
\hline Gas sum 1 & ? & & & \\
\hline \multicolumn{5}{|l|}{ Ha1dager 1} \\
\hline Horsens 1 & $? 1319-1506 m$ & $\mathrm{SP}+\operatorname{Res} / \mathrm{SP}+\operatorname{Res}$ & $1262-1449$ & 187 \\
\hline Nors 1 & $2510-2768.4 \mathrm{~m}$ & ITT/ITT & $2492-2750$ & 258 \\
\hline N\$vi ing 1 & $1572-1847 \mathrm{~m}$ & $\operatorname{ITT}(+\mathrm{GR}) / \mathrm{ITT}+\mathrm{N}$ & $1505-1778$ & 275 \\
\hline Ronde 1 & $2409-2613.6 \mathrm{~m}$ & $G R+1 T T / G R+1 T T$ & $2367-2571$ & 205 \\
\hline \multicolumn{5}{|l|}{ Skagen 2} \\
\hline Slagelse 1 & $973-1150 m$ & $G R+N / G R+N$ & $932-1109$ & 177 \\
\hline histed 1 & $636-745.8 m$ & $\mathrm{GR} / \mathrm{ITT}(+\mathrm{GR})$ & $600-710$ & 110 \\
\hline \\
\hline disted 1 & $\begin{array}{l}1604-1897.5 \mathrm{~m} \\
1665-1795 \mathrm{~m}\end{array}$ & $S \mathrm{P}+\mathrm{Re} / \mathrm{SP}$ & $\begin{array}{l}1599-1892 \\
1649-1779\end{array}$ & $994^{\circ}$ \\
\hline
\end{tabular}

x) Inclusive intercalations of the Gassum formation

MEMBER F-IV (FJERRITSLEY FORMATION)

\begin{tabular}{|c|c|c|c|c|}
\hline Boring & $\begin{array}{l}\text { Depth } b . \text { kB } \\
\text { (m or feet) }\end{array}$ & $\begin{array}{c}\log \\
\text { (characterizing) }\end{array}$ & $\begin{array}{l}\text { Depth b.MSL } \\
\qquad(\mathrm{m})\end{array}$ & $\begin{array}{c}\text { Thickne: } \\
\text { (m) }\end{array}$ \\
\hline Børglum 1 & $3529-3886.5$ & $S P / S P$ & $1053-1162$ & 109 \\
\hline \multicolumn{5}{|c|}{ Dansk Nords $\phi-1$} \\
\hline Dansk Nords $\varnothing \mathrm{J}-1$ & $3646-3788^{\prime}$ & $\operatorname{ITT}(+G R) / I T T$ & $1074-1117$ & 43 \\
\hline Dansk Nords $\$ k-1$ & $4659-4690^{\prime}$ & $\mathrm{ITT}+\mathrm{Ca} 1 / \mathrm{GR}+\mathrm{SP}$ & $1383-1392$ & \\
\hline Fjerritslev 2 & $1322-1399 \mathrm{n}$ & $\mathrm{SP}+\operatorname{Res} / \mathrm{SP}+\mathrm{ReS}$ & $1314-1391$ & 77 \\
\hline F1yvbjerg 1 & $1045-1096 \mathrm{~m}$ & $\mathrm{SP} / \mathrm{SP}+\mathrm{ReS}$ & $998-1049$ & 51 \\
\hline Frederikshavn 1 & $2417-2492^{\circ}$ & $\mathrm{SP}+\operatorname{Res} / \mathrm{SP}+\operatorname{ReS}$ & $724-747$ & 3 \\
\hline $\begin{array}{l}\text { Frederikshavn } 2 \\
\text { Gassum } 1\end{array}$ & $2333-2402$ & $\mathrm{SP}+\mathrm{GR} / \mathrm{SP}+\mathrm{Res}$ & $696-717$ & \\
\hline $\begin{array}{l}\text { Haldager } 1 \\
\text { Horsens } 1\end{array}$ & $4198.5-4616.5$ & $\mathrm{SP} / \mathrm{SP}$ & $1275-1402$ & 127 \\
\hline $\begin{array}{l}\text { Mors } 1 \\
\text { Nov1 ing } 1\end{array}$ & $2155-2179.5 \mathrm{~m}$ & $\mathrm{GR}(+\mathrm{ITT}) / \mathrm{GR}+\mathrm{ITT}$ & $2137-2162$ & 25 \\
\hline Ronde 1 & $2138.2-2193.2 \mathrm{~m}$ & GR+ITT/N & $2096-2151$ & 55 \\
\hline Skagen 2 & $1460-1554.5^{\prime}$ & $\mathrm{SP} / \mathrm{SP}+\mathrm{ReS}$ & $443-472$ & 29 \\
\hline S1agelse 1 & & & & \\
\hline Thisted 1 & & & & \\
\hline Uglev 1 & & & & \\
\hline $\begin{array}{l}\text { Vedsted } 1 \\
\text { vemb } 1\end{array}$ & $1224-1257.5 \mathrm{~m}$ & $\mathrm{SP}+\mathrm{ReS} / \mathrm{SP}+\mathrm{ReS}$ & $1219-1252$ & 34 \\
\hline
\end{tabular}

MEMBER F-II (FJERRITSLEV FORMATION)

\begin{tabular}{|c|c|c|c|c|}
\hline Boring & $\begin{array}{l}\text { Veptn b. KB } \\
\text { (m or feet) }\end{array}$ & $\begin{array}{l}\log \\
\text { (characterizing) }\end{array}$ & $\begin{array}{l}\text { Depth b.MSL } \\
\text { (m) }\end{array}$ & $\begin{array}{c}\text { Thicknes } \\
(\mathrm{m})\end{array}$ \\
\hline Bøprglun 1 & $4217-4414^{\prime}$ & $S P+\operatorname{Res} / \operatorname{Res}$ & $1263-1323$ & 60 \\
\hline Dansk Nords $\phi F-1$ & $5896-6155^{\prime}$ & $\mathrm{GR}+\mathrm{SP} / \mathrm{GR}+\mathrm{ITT}$ & $1760-1839$ & 79 \\
\hline Dansk Nords; $J-1$ & $4110-4694^{\circ}$ & GR (ITT)/ITT+GR & $1215-1393$ & 178 \\
\hline Dansk Nords $k-1$ & $4914-5162^{\prime}$ & $\mathrm{ITT}+\mathrm{Ca} 1 / \mathrm{ITT}+\mathrm{Res}$ & $1461-1536$ & 76 \\
\hline Fjerritslev 2 & $1678-1857 \mathrm{~m}$ & $\mathrm{SP}+\operatorname{Res} / \operatorname{Res}$ & $1670-1849$ & 179 \\
\hline F:1yvbjerg 1 & $1184.5-1272 \mathrm{~m}$ & $(\mathrm{SP}+\mathrm{ReS}) / \mathrm{SP}+\mathrm{ReS}$ & $1137-1225$ & 88 \\
\hline Frederikslavn 1 & $2668-2932^{\circ}$ & $\mathrm{SP}+\mathrm{Re} S / \mathrm{SP}+\mathrm{ReS}$ & $800-881$ & 80 \\
\hline Frederiksnavn 2 & $2580-2850^{\circ}$ & $S P+G R+R e s / S P(+R e s)$ & $771-855$ & 84 \\
\hline Gassun 1 & ? & & & \\
\hline \multicolumn{5}{|l|}{ Haldager 1} \\
\hline Horsens 1 & $? 1296-1319 \mathrm{~m}$ & $\mathrm{SP}+\operatorname{Re} s / \mathrm{SP}+\operatorname{Res}$ & $1239-1262$ & 23 \\
\hline Sors 1 & $2327.3-2510 \mathrm{~m}$ & GR/ITT & $2309-2492$ & 183 \\
\hline Noviling 1 & $1512-1572 m$ & $\mathrm{ITT} / \mathrm{ITT}(+\mathrm{GR})$ & $1443-1503$ & 60 \\
\hline Rønde 1 & $2337.7-2409 \mathrm{~m}$ & $G R+I T T / G R+I T T$ & $2296-2367$ & 71 \\
\hline Skagen 2 & $?$ & & & \\
\hline \multicolumn{5}{|l|}{ Slagelse 1} \\
\hline \multicolumn{5}{|l|}{ fhisted 1} \\
\hline \multicolumn{5}{|l|}{ glev 1} \\
\hline edsted 1 & $1475-1604 \mathrm{~m}$ & $\operatorname{Res}[+\mathrm{SP}] / \mathrm{SP} \bullet \operatorname{Res}$ & $1470-1599$ & 129 \\
\hline emb 1 & $1627.5-1665 \mathrm{~m}$ & $\mathrm{SP}+\mathrm{ReS} / \mathrm{SP}+\mathrm{ReS}$ & $1612-1649$ & 38 \\
\hline
\end{tabular}

HALDAGER FORMATION

\begin{tabular}{|c|c|c|c|c|}
\hline Boring & $\begin{array}{l}\text { Depth b. KB } \\
\text { (m or feet) }\end{array}$ & $\begin{array}{c}\log \\
\text { (characterizing) }\end{array}$ & $\begin{array}{l}\text { Depth b.MSL } \\
\text { (m) }\end{array}$ & $\begin{array}{c}\text { Thicknes } \\
\text { (m) }\end{array}$ \\
\hline Børg1um 1 & $3323-3529^{\prime}$ & $S P+\operatorname{Res} / S P$ & $990-1053$ & 63 \\
\hline Dansk Nordsø F-1 & 5743-5896 & $G R * S P / G R * S P$ & $1713-1760$ & 47 \\
\hline lansk Nords $₫ J-1$ & $3584-3646^{\prime}$ & $G R+1 T T / I T T(+6 R)$ & $1055-1074$ & 19 \\
\hline Dansk Nords $\$ k-1$ & $4554-4659^{\prime}$ & GR/ITT+Cal & $1351-1383$ & 32 \\
\hline Fjerritslev 2 & $1263.5-1322 \mathrm{~m}$ & $S P+\operatorname{Res} / S P(+R e s)$ & $1256-1314$ & s9 \\
\hline Flyvbjerg 1 & $951-1045$ & $S P / S P$ & 904-998 & 94 \\
\hline Frederikshavn 1 & $2130-2417^{\prime}$ & $S P \bullet \operatorname{Res} / \mathrm{SP}+\operatorname{Res}$ & $636-724$ & 87 \\
\hline $\begin{array}{l}\text { Frederikshavn } 2 \\
\text { Gassum } 1\end{array}$ & 2029-2333' & $\mathrm{SP}(\bullet \mathrm{GR}) / \mathrm{SP}+\mathrm{GR}$ & $603-696$ & 9 \\
\hline Haldager 1 & $3520-4198.5^{\circ}$ & SP+Res/SP & $1068-1275$ & 207 \\
\hline Horsens 1 & $1292-1296 m$ & $\mathrm{SP}+\operatorname{Res} / \mathrm{SP}+\operatorname{Res}$ & 1235-1239 & 4 \\
\hline Mors 1 & $2008.5-2155 \mathrm{~m}$ & $\mathrm{GR}+\mathrm{N}+\mathrm{ITT} / \mathrm{GR}(+\mathrm{ITT})$ & $1991-2137$ & 147 \\
\hline Novling 1 & & & & \\
\hline onde 1 & & & & \\
\hline Skagen 2 & $1282-1460^{\prime}$ & $S P+R e s / S P$ & $389-443$ & 54 \\
\hline 1agelse 1 & & & & \\
\hline Thisted 1 & $604.6-636 \mathrm{~m}$ & GR/GR & $569-600$ & 31 \\
\hline Ug1ev 1 & $2904-3103^{\prime}$ & $\mathrm{SP} /(\mathrm{SP})$ & $849-910$ & 61 \\
\hline Vedsted 1 & $1124-1224 \mathrm{~m}$ & $S P+\operatorname{Res} / \mathrm{SP}(+\operatorname{Res})$ & 1119-1219 & 100 \\
\hline emb 1 & $1571-1590.5 \mathrm{~m}$ & $S P / S P$ & $1555-1575$ & 2 \\
\hline
\end{tabular}




\section{HALDAGER SAND (HALDAGER FORMATION)}

\begin{tabular}{|c|c|c|c|c|}
\hline Boring & $\begin{array}{l}\text { Depth } b, K B \\
\text { (m or feet) }\end{array}$ & $\begin{array}{c}\log \\
\text { (characterizing) }\end{array}$ & $\begin{array}{l}\text { Depth b.MSL } \\
\text { (m) }\end{array}$ & $\begin{array}{c}\text { Thickne } \\
(m)\end{array}$ \\
\hline B $\phi \dot{q} g$ lum 1 & $3435-3529^{\circ}$ & SP/SP & 1024-1053 & 29 \\
\hline Dansk Nords $\phi F-1$ & $=5836-5896^{\circ}$ & $S P / G R+S P$ & $1741-1760$ & 18 \\
\hline Dansk Nords $\phi J-1$ & $3584-3646^{\circ}$ & $G R+I T T / I T T(* G R\}$ & $1055-1074$ & 19 \\
\hline Dansk Nords $\mathrm{k}-1$ & $4608-4659^{\prime}$ & $\mathrm{ITT}+\mathrm{Ca} 1 / \mathrm{ITT}+\mathrm{Ca} 1$ & $1367-1383$ & 16 \\
\hline Fjerritslev 2 & $1287.5-1322 \mathrm{~m}$ & $\mathrm{SP} / \mathrm{SP}(+\operatorname{Res})$ & $1280-1514$ & 35 \\
\hline F1yvbjerg 1 & $991-1045 \mathrm{~m}$ & $\mathrm{SP} / \mathrm{SP}$ & $944-998$ & 54 \\
\hline Frederikshavn 1 & $2302-2417^{\circ}$ & $S P(+$ Res $) / S P+$ Res & $689-724$ & 35 \\
\hline $\begin{array}{l}\text { Frederikshavn } 2 \\
\text { Gassum } 1\end{array}$ & $2182-2333$ & $\mathrm{SP} / \mathrm{SP}+\mathrm{GR}$ & $650-696$ & 46 \\
\hline Haldager 1 & $3693-4198.5^{\prime}$ & $\mathrm{SP} / \mathrm{SP}$ & $1120-1275$ & 154 \\
\hline Horsens 1 & $1292-1296 \mathrm{~m}$ & $S P+R e s / S P+R e s$ & $1235-1239$ & 4 \\
\hline Mors 1 & $? 2033-2155 \mathrm{~m}$ & $/ \mathrm{GR}(+\mathrm{ITT})$ & $2015-2137$ & 122 \\
\hline \multicolumn{5}{|l|}{ Nøvling 1} \\
\hline \multicolumn{5}{|l|}{ Rønde 1} \\
\hline Skagen 2 & $1414.5-1460^{\circ}$ & $S P / S P$ & $429-443$ & 14 \\
\hline \multicolumn{5}{|l|}{ Slagelse 1} \\
\hline Thisted 1 & $604.6-636 \mathrm{~m}$ & $\mathrm{GR} / \mathrm{GR}$ & $569-600$ & 31 \\
\hline Uglev 1 & $2980-3103$. & $\mathrm{SP} /(\mathrm{SP})^{\prime}$ & $873-910$ & 37 \\
\hline Vedsted 1 & $1149-1224 m$ & $\mathrm{SP}+$ Res $/ \mathrm{SP}+$ Res & $1144-1219$ & 75 \\
\hline Vemb I & $1581.5-1590.5 \mathrm{~m}$ & $\mathrm{SP} / \mathrm{SP}$ & $1566-1575$ & . \\
\hline
\end{tabular}

\section{BgrgLUM MEMBER (BREAM FORMATION)}

\begin{tabular}{|c|c|c|c|c|}
\hline Boring & $\begin{array}{l}\text { Depth b. KB } \\
\text { (m or feet) }\end{array}$ & $\begin{array}{c}\log \\
\text { (characterizing) }\end{array}$ & $\begin{array}{l}\text { Depth b.MSL } \\
\text { (m) }\end{array}$ & $\begin{array}{c}\text { Thickne } \\
(m)\end{array}$ \\
\hline B $\phi \mathbf{r g} \operatorname{lum} 1$ & $3213-3323$ & $(S P+R e s) / S P+R e S$ & $957-990$ & 34 \\
\hline Dansk Nords $\phi F-1$ & $5472-5743^{\prime}$ & $G R(+I T T) / G R+S P$ & $1631-1713$ & 83 \\
\hline Dansk Nords $\$ J-1$ & $3251-3584^{\circ}$ & $G R+I T T / G R+I T T$ & $954-1055$ & 101 \\
\hline \multicolumn{5}{|c|}{ Dansk Nordsø $k-1$ + } \\
\hline Fjerritslev 2 & $1151-1263.5 m$ & $(S P+\operatorname{Res}) / S P+\operatorname{Res}$ & $1143-1256$ & 113 \\
\hline Flyvbjerg 1 & $922-951 \mathrm{~m}$ & $(\mathrm{SP}+\mathrm{Res}) / \mathrm{SP}$ & $875-904$ & 29 \\
\hline Frederikshavn 1 & $2104-2130^{\circ}$ & $\operatorname{Res}(+\mathrm{SP}) / \mathrm{SP}+\operatorname{Res}$ & $629-636$ & 8 \\
\hline Frederikshavn 2 & $1997-2029^{\prime}$ & $\operatorname{Res}(+S P) / S P(+\operatorname{Res})$ & $593-603$ & 10 \\
\hline Gassum 1 & $3868-3931^{\prime}$ & GR/GR & $1121-1140$ & 19 \\
\hline Ha1dager 1 & $3374-3520^{\circ}$ & {$[\operatorname{Res}] / \mathrm{SP} * \mathrm{Res}$} & $1023-1068$ & 45 \\
\hline Horsens 1 & $1287-1292 \mathrm{~m}$ & $\mathrm{SP}+\mathrm{ReS} / \mathrm{SP}+\operatorname{ReS}$ & $1230-1235$ & 5 \\
\hline Mors 1 & $1886-2008.5 m$ & $\mathrm{ITT} / \mathrm{ITT}$ & $1868-1991$ & 123 \\
\hline N $\phi v 1$ ing 1 & $1494-1512 \mathrm{~m}$ & GR+N+ITT/ & $1425-1443$ & 18 \\
\hline Rønde 1 & $2099.7-2138.2$ & $G R+I T T / N$ & $2058-2096$ & 39 \\
\hline Skagen 2 & $1269-1282^{\circ}$ & $S P+\operatorname{Res} / \mathrm{SP}+\operatorname{Res}$ & $385-389$ & 4 \\
\hline \multicolumn{5}{|l|}{ Slage 1 se 1} \\
\hline Thisted & $525-604.6 \mathrm{~m}$ & GR+ITT/GR & $489-569$ & 80 \\
\hline Uglev 1 & $?$ & & & \\
\hline dsted 1 & $1076-1124 m$ & $(\operatorname{Res}) / \mathrm{SP}+$ Res & $1071-1119$ & 48 \\
\hline
\end{tabular}

\section{FLYVBJERG MEMBER (HALDAGER FOPMATION)}

\begin{tabular}{|c|c|c|c|c|}
\hline Boring & $\begin{array}{l}\text { Depth b. } \mathrm{kB} \\
\text { (m or feet) }\end{array}$ & $\begin{array}{c}\log \\
\text { (characterizing) }\end{array}$ & $\begin{array}{l}\text { Depth b.MSL } \\
\text { (m) }\end{array}$ & $\begin{array}{c}\text { Thickne } \\
\text { (n) }\end{array}$ \\
\hline orglum 1 & $3323-3435^{\prime}$ & $S P+R e s / S P$ & $990-1024$ & 34 \\
\hline pensk Nordsø F-1 & $? 5743-5836$ & $G R+S P / S P$ & $1713-1741$ & 28 \\
\hline Dansk Nords $J-1$ & $4554-4608$ & $\mathrm{GR} / \mathrm{ITT} * \mathrm{Ca} 1$ & $1351-1367$ & 16 \\
\hline Fjerritslev 2 & $1263.5-1287.5 \mathrm{~m}$ & $\mathrm{SP}+\operatorname{Res} / \mathrm{SP}$ & $1256-1280$ & 24 \\
\hline 1yvbjerg 1 & $951-991 \mathrm{n}$ & $\mathrm{SP} / \mathrm{SP}$ & $904-944$ & 40 \\
\hline rederikshavn 1 & $2130-2302^{\circ}$ & $S P+\operatorname{Res} / \mathrm{SP}(+\operatorname{Res})$ & $636-689$ & 52 \\
\hline $\begin{array}{l}\text { Frederikshavn } 2 \\
\text { Gassum } 1\end{array}$ & $2029-2182^{\prime}$ & $\mathrm{SP}(+\mathrm{GR}) / \mathrm{SP}$ & $603-650$ & 47 \\
\hline $\begin{array}{l}\text { Haldager } 1 \\
\text { Horsens } 1\end{array}$ & $3520-3693^{\prime}$ & $\mathrm{SP}+\mathrm{Re}-/ \mathrm{SP}$ & $1068-1120$ & 53 \\
\hline $\begin{array}{l}\text { Mors } 1 \\
\text { Nøv ing } 1 \\
\text { Rønde } 1\end{array}$ & $? 2008.5-2033 \mathrm{~m} \mathrm{GR}$ & $\mathrm{R}+\mathrm{N}+\mathrm{ITT} /$ & $1991-2015$ & 25 \\
\hline $\begin{array}{l}\text { Skagen } 2 \\
\text { Slagelse } 1 \\
\text { Thisted } 1\end{array}$ & $1282-1414.5^{\prime}$ & $S P+\operatorname{Res} / S P$ & $389-429$ & 40 \\
\hline glev 1 & $2904-2980^{\prime}$ & $S P / S P$ & $849-873$ & 23 \\
\hline edsted 1 & $1124-1149 m$ & $S P+\operatorname{Res} / S \mathrm{P}+\operatorname{Res}$ & $1119-1144$ & 25 \\
\hline & $-1581.5 \mathrm{~m}$ & $\mathrm{SP} / \mathrm{SP}$ & $555-1566$ & \\
\hline
\end{tabular}

Vemb 1

1571-1581.5m SP/SP $1555-1566$

\section{PEAM FOPMATIO}

\begin{tabular}{|c|c|c|c|c|}
\hline Boring & $\begin{array}{l}\text { Depth b. KB } \\
\text { (m or feet) }\end{array}$ & $\begin{array}{l}\log \\
\text { (Wharacterizing) }\end{array}$ & $\begin{array}{l}\text { Bepth b.MSL } \\
\text { (m) }\end{array}$ & $\begin{array}{c}\text { Thicknes } \\
\text { (m) }\end{array}$ \\
\hline Børglum 1 & $2478.5-3323{ }^{\prime}$ & $S \mathrm{P}+\mathrm{Re} S / \mathrm{SP}+\mathrm{ReS}$ & $733-990$ & 257 \\
\hline Dansk Nords $\$$ F- 1 & $5079-5743^{\circ}$ & $\dot{R} R+1 T T / G R+S P$ & $1511-1713$ & 202 \\
\hline Dansk Nords $\$ \mathrm{~J}-1$ & $2655-3584^{\circ}$ & GR/GR+ITT & $772-1055$ & 283 \\
\hline Uansk Nords $\$$ k- 1 & $4190-4554^{\circ}$ & GR/GR & $1240-1351$ & 111 \\
\hline Fjerritslev 2 & $1009-1263.5 \mathrm{~m} \mathrm{C}$ & $(5 \mathrm{~F}+\mathrm{Re} s) / \mathrm{SP}+\operatorname{Res}$ & $1001-1256$ & 255 \\
\hline Fiyvbjerg 1 & $750-951 \mathrm{~m}$ & SP+Res/SP & $703-904$ & 201 \\
\hline Frederikshavn 1 & $1665-2130^{1}$ & $G R+5 P+R e s / S P+R e s$ & $495-636$ & 142 \\
\hline Frederikshavn 2 & $1566-2029^{\prime}$ & jP+Res/(Res)+SP & $462-603$ & 141 \\
\hline Gassum 1 & $3538-3931^{\circ}$ & $\mathrm{GR} / \mathrm{GR}$ & $1020-1140$ & 120 \\
\hline HaIdager 1 & $2576-3520^{\circ}$ & $S P * j R+R e s / S P+R e s$ & $780-1068$ & 288 \\
\hline Horsens : & $1225-1292 \pi$ & SP+Res $/ S \mathrm{P}+$ Res & $1168-1235$ & 67 \\
\hline Mors 1 & $1749-2008.5 \mathrm{~m}$ & $\mathrm{ITT} / \mathrm{ITT}$ & $1731-1991$ & 260 \\
\hline Nov1ing 1 & $1394.5-1512 \mathrm{~m} \mathrm{G}$ & $G R \cdot N+I T T / I T T$ & $1325-1443$ & 118 \\
\hline Rønde 1 & $2049.7-2138.2 \mathrm{~m}$ & m $: R+I T T / N$ & $2008-2096$ & 89 \\
\hline Skagen 2 & 640-1282' & $S P+\operatorname{Res} / S P+\operatorname{Res}$ & 193-389 & 196 \\
\hline \multicolumn{5}{|l|}{ Slage1se 1} \\
\hline Thisted 1 & $525-604.6 \mathrm{~m}$ & i $R+I T T / G R$ & $489-569$ & 80 \\
\hline Uglev 1 & $2678-2904^{\circ}$ & SP/SP & $816-885$ & 69 \\
\hline Vedsted 1 & $841-1124 m$ & $\mathrm{SP} / \mathrm{SP}+\mathrm{ReS}$ & $836-1119$ & 283 \\
\hline$m b 1$ & $? 1557-1571 \mathrm{~m}$ & & & \\
\hline
\end{tabular}

\section{FREDERI KSHAVN MEMBER (BREAM FORMATION)}

\begin{tabular}{|c|c|c|c|c|}
\hline Boring & $\begin{array}{l}\text { Depth b. KB } \\
\text { (m or feet) }\end{array}$ & $\begin{array}{c}\text { Log } \\
\text { (characterizing) }\end{array}$ & $\begin{array}{c}\text { Depth b.MSL } \\
(m)\end{array}$ & $\begin{array}{c}\text { Thickne } \\
(\mathrm{m})\end{array}$ \\
\hline Børglum 1 & $2478.5-32131$ & $\mathrm{SP}+\mathrm{ReS} /(\mathrm{SP}+\mathrm{Res})$ & $733-957$ & 224 \\
\hline Dansk Nords $\& \mathrm{~F}-1$ & $5079-5472^{\prime}$ & $G R+I T T / G R(+I T T)$ & $1511-1631$ & 120 \\
\hline Dansk Nords $₫ \mathrm{~J}-1$ & $2655-3251^{\circ}$ & $G R / G R+I T T$ & $772-954$ & 182 \\
\hline \multicolumn{5}{|c|}{ Dansk Nords $\phi$ K-1 } \\
\hline Fjerritslev 2 & $1009-1151 \mathrm{~m}$ & $(\mathrm{SP}+\mathrm{Res}) /(\mathrm{SP}+\mathrm{ReS})$ & $1001-1143$ & 142 \\
\hline F1yvbjerg 1 & $750-922 \mathrm{~m}$ & $\mathrm{SP}+\operatorname{Res} /(\mathrm{SP} * \mathrm{ReS})$ & $703-875$ & 172 \\
\hline Frederikshavn 1 & $1665-2104$ & $G R+S P+\operatorname{Res} / \operatorname{Res}(+S P)$ & $495-629$ & 134 \\
\hline Frederikshavn 2 & $1566-1997$ & $S P+\operatorname{Res} / \operatorname{Res}(+S P)$ & $462-593$ & 131 \\
\hline Gassum 1 & $3538-3868^{\prime}$ & GR/GR & $1020-1121$ & 101 \\
\hline Haldager 1 & $2576-3374^{\prime}$ & $S P+G R+\operatorname{Res} /(\operatorname{Res})$ & $780-1023$ & 243 \\
\hline Horsens 1 & $1225-1287 \mathrm{~m}$ & $\mathrm{SP}+\mathrm{Re} S / \mathrm{SP}+\mathrm{ReS}$ & $1168-1230$ & 62 \\
\hline Mors 1 & $1749-1886 \mathrm{~m}$ & ITT/ITT & $1731-1868$ & 137 \\
\hline N $\phi v$ ling 1 & $1394.5-1494 \mathrm{~m}$ & $G R+N+I T T / G R+N+I T T$ & $1325-1425$ & 100 \\
\hline Ronde 1 & $2049.7-2099.7 \mathrm{~m}$ & $\mathrm{~m} \quad \mathrm{GR}+\mathrm{ITT} / \mathrm{GR}+\mathrm{ITT}$ & 2008-2058 & so \\
\hline Skagen $z$ & $640-1269^{\prime}$ & $S P+\operatorname{Res} / S P+\operatorname{ReS}$ & $193-385$ & 192 \\
\hline \multicolumn{5}{|l|}{ Slagelse 1} \\
\hline Thisted 1 & ? & & & \\
\hline Uglev 1 & ? & & & \\
\hline Vedsted 1 & $841-1076 m$ & SP/(Res) & $836-1071$ & 235 \\
\hline 100 & & & & \\
\hline
\end{tabular}

TABLE 1, JURASSIC FORMATIONS AND MEMBERS OF THE NORWEGI AN-DANISH BASIM

Legend:

Log Wire line logs used for identification of the boundary

SP Spontaneous potentia

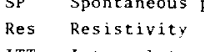

ITT Interval transit time

GR Gamma ray

$\begin{array}{ll}N & \text { Neutron } \\ \text { Cal } & \text { Caliper }\end{array}$

/ Upper / lower boundary

TD Total depth of the boring

MSL Mean sea level
KB Kelly bushing

The thickness is calculated from the depth below $K B$ 


\section{References}

Al-Kasim, F., Rønnevik, H. C. \& Ulleberg, K. 1975: Review of the Jurassic Offshore Norway. - NPF-Jurassic Northern North Sea Symposium, Stavanger.

Bertelsen, F. 1975: Triassic palynology and stratigraphy of some Danish North Sea boreholes. - Danm. geol. Unders., Åbog 1974, pp. 17-32.

Brooks, J. R. V. \& Chesher, J. A. 1975: Review of the Offshore Jurassic of the UK Northern North Sea. - NPF-Jurassic Northern North Sea Symposium, Stavanger.

Christensen, O. B. 1971: De yngre jurassiske aflejringer og grænsen jura-kridt i Rønde nr. 1 (Eng. summary). - In: Rasmussen et al. 1971 , pp. $68-73$.

Christensen, O. B. 1973: De nedre kretaciske og øvre jurassiske formationer og ostracodfaunaer i Nøvling nr. 1 (1329-1509 m). (Eng. summary). - In: Rasmussen et al. 1973, pp. 113-118.

Christensen, O. B. 1974: Marine communications through the Danish Embayment during uppermost Jurassic and lowermost Cretaceous. - Geoscience and Man, VI, October 1, 1974, pp. 99-115.

Davey, R. J. (1976): The stratigraphic distribution of dinocysts in the Portlandian (Latest Jurassic) to Barremian (Early Cretaceous) of Northwest Europe. - Unpublished report.

Decgan, C. E.\& Scull, B. J. (ed.) 1977: A standard lithostratigraphic nomenclature for the Central and Northern North Sea.Inst. geol. Sc., Report No. 74/8, 36 p.

Fuller, J. G. C. M. 1975: Jurassic Source-Rock Potential and Hydrocarbon correlation, North Sea. - NPF-Jurassic Northern North Sea Symposium, Stavanger.

Larsen, G. 1966: Rhaetic-Jurassic-Lower Cretaceous Sediments in the Danish Embayment (A Heavy-Mineral Study). - Danm. geol. Unders., II række, 91, 127 p.

Michelsen, O. 1971: Nedre jura og nederste mellem jura i Rønde nr. 1. Biostratigrafisk undersøgelse på grundlag af ostracoder. (Eng. summary). - In: Rasmussen et al. 1971, pp. 81-88.

Michelsen, O. 1973: Nedre jura i Nøvling nr. 1 (1509-1847 m). Biostratigrafi baseret på ostracoder. (Eng. summary). - In: Rasmussen et al. 1973, pp. 124-131.

Michelsen, O. 1975: Lower Jurassic biostratigraphy and ostracods of the Danish Embayment. - Danm. geol. Unders., II. række, $104,287 \mathrm{p}$.

Michelsen, O. 1976a: Preliminary report on the Jurassic lithostratigraphic nomenclature in the Danish North Sea area. - Danm. geol. Unders., Arbog 1975, pp. 105-116.

Michelsen, O. 1976b: Kortfattet oversigt over de geologiske forhold i den danske del af Nordsøen. - Danm. geol. Unders., Årbog 1975, pp. 117-132.

Michelsen, O. 1977: Jurassic deposits of the Norwegian-Danish Basin. - Mesozoic Northern North Sea Symposium. Oslo.

Norling, E. 1972: Jurassic Stratigraphy and Foraminifera of Western Scania, Southern Sweden. - Sver. geol. Unders. Afh., Ser. Ca, 47, 120 p.

Norwegian Petroleum Directorate, NPD Paper Nos. 1-9, 1975-1977.

Rasmussen, L. B. 1978: Geological aspects of the Danish North Sea sector. With a report on the wells Dansk Nordsø $\mathrm{E}-1, \mathrm{E}-2$, F-1, G-1, H-1, I-1, J-1, and K-1. - Danm. geol. Unders., III. rakke, 44 (in prep.).

Rasmussen, L. B., Dinesen, A., Henriksen, S. E., Bang, I., Stenestad, E., Buch, A., Christensen, O. B., Michelsen, O. \& Jacobsen, F. L. 1971: Dybdeboringen Rønde nr. 1 på Djursland. (Eng. summary). - Danm. geol. Unders., III. rakke, 39, 123 p.
Rasmussen, L. B., Baartman, J. C., Henriksen, S. E., Kristoffersen, F. N., Dinesen, A., Bang, I., Stenestad, E., Buch, A., Christensen, O. B., Michelsen, O., Hansen, T. J. \& Jacobsen, F. L. 1973: Dybdeboringen Novling nr. 1 i Midtjylland. (Eng. summary). - Danm. geol. Unders., III. række, 40, 164 p.

Rolle, F., Koch, J. O., Frandsen, N. \& Surlyk, F.: Jurassic Environments in the Fenno-Scandian Border Zone. - Paper presented at "Symposium on the Jurassic Sedimentation of Western Europe", Paris, May 1977.

Rønnevik, H. C., van den Bosch, W. \& Bandlien, E. H. 1975: A proposed nomenclature for the main structural features in the Norwegian North Sea. - NPF-Jurassic Northern North Sea Symposium, Stavanger.

Sorgenfrei, T. 1969: Geological perspectives in the North Sea area. - Bull. geol. Soc. Denmark, 19, pp. 160-196.

Sorgenfrei, T. \& Buch, A. 1964: Deep Tests in Denmark 1935-1959. - Danm. geol. Unders., III. række, 36, 146 p.

Tralau, H. 1966: Botanical investigations in the fossil flora of Eriksdal in Fyledalen, Scania. - Sver. geol. Unders., Ser. C, 611 , $33 \mathrm{p}$.

Well data summary Sheets, Vol. 1-2. 1976. - Oljedirektoratet.

Younge, B., Myrland, R., Taylor, H. \& Ruble, C. L. 1975: A preliminary report from the Jurassic stratigraphic nomenclature subcommittee in Norway. - NPF-Jurassic Northern North Sea Symposium, Stavanger.

Ziegler, W. H. 1975: Outline of the geological history of the North Sea. - In: Woodland, A. W. (ed.) 1975. - Petroleum and the continental shelf of North-West Europe, vol. 1, Geology. London. 

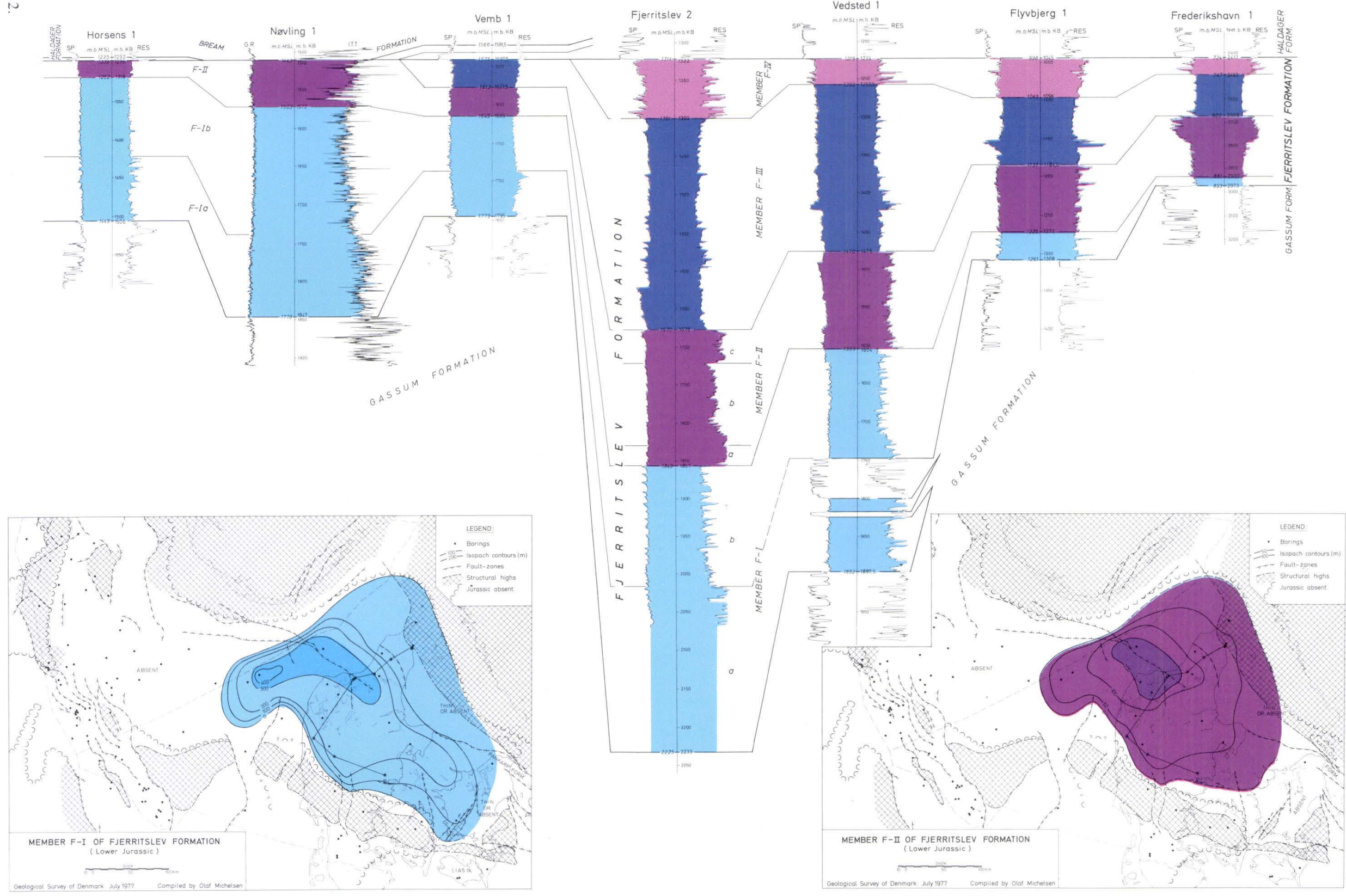
FJERRITSLEV FORMATION in the Norwegian-Danish Basin

$\bar{c}$

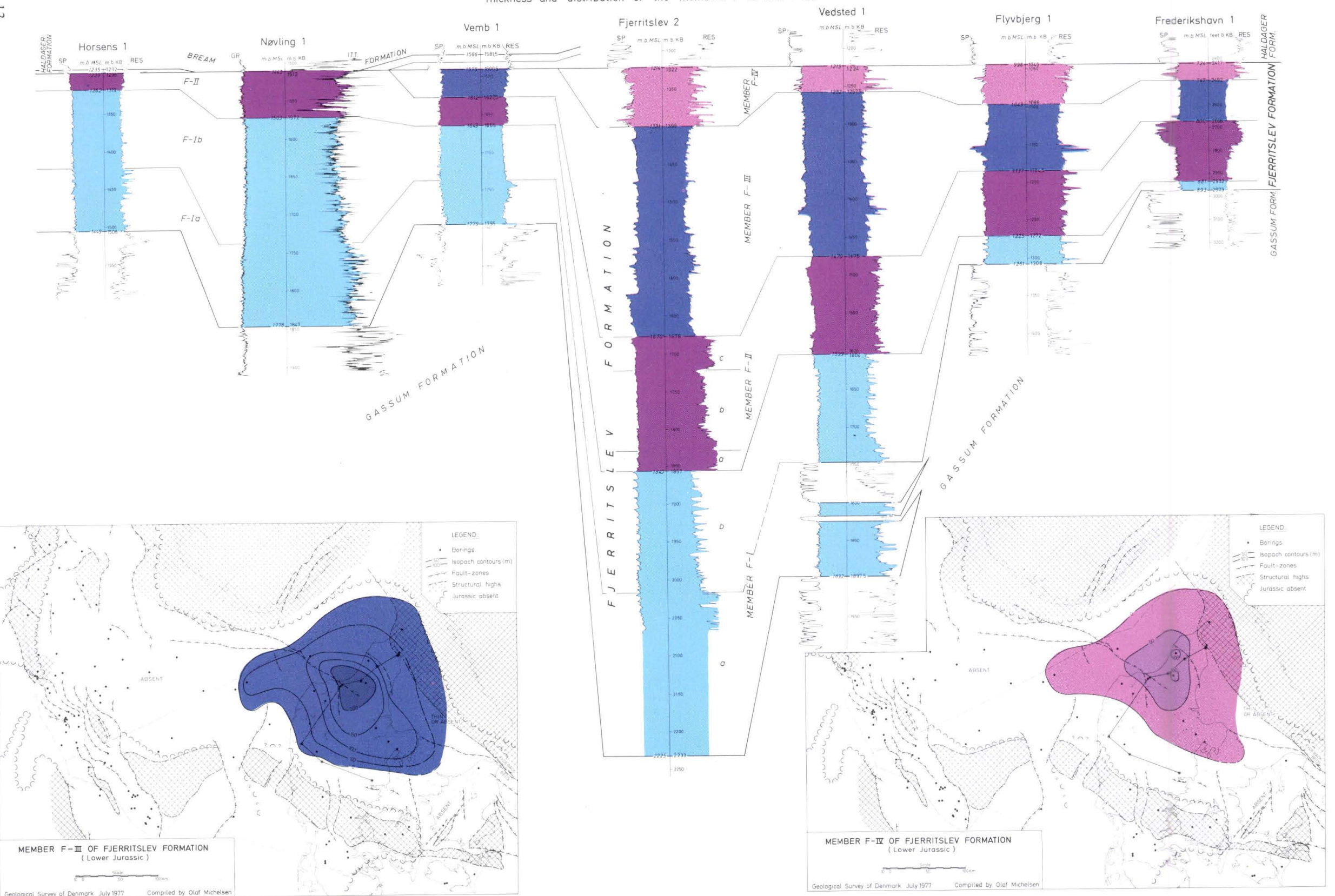



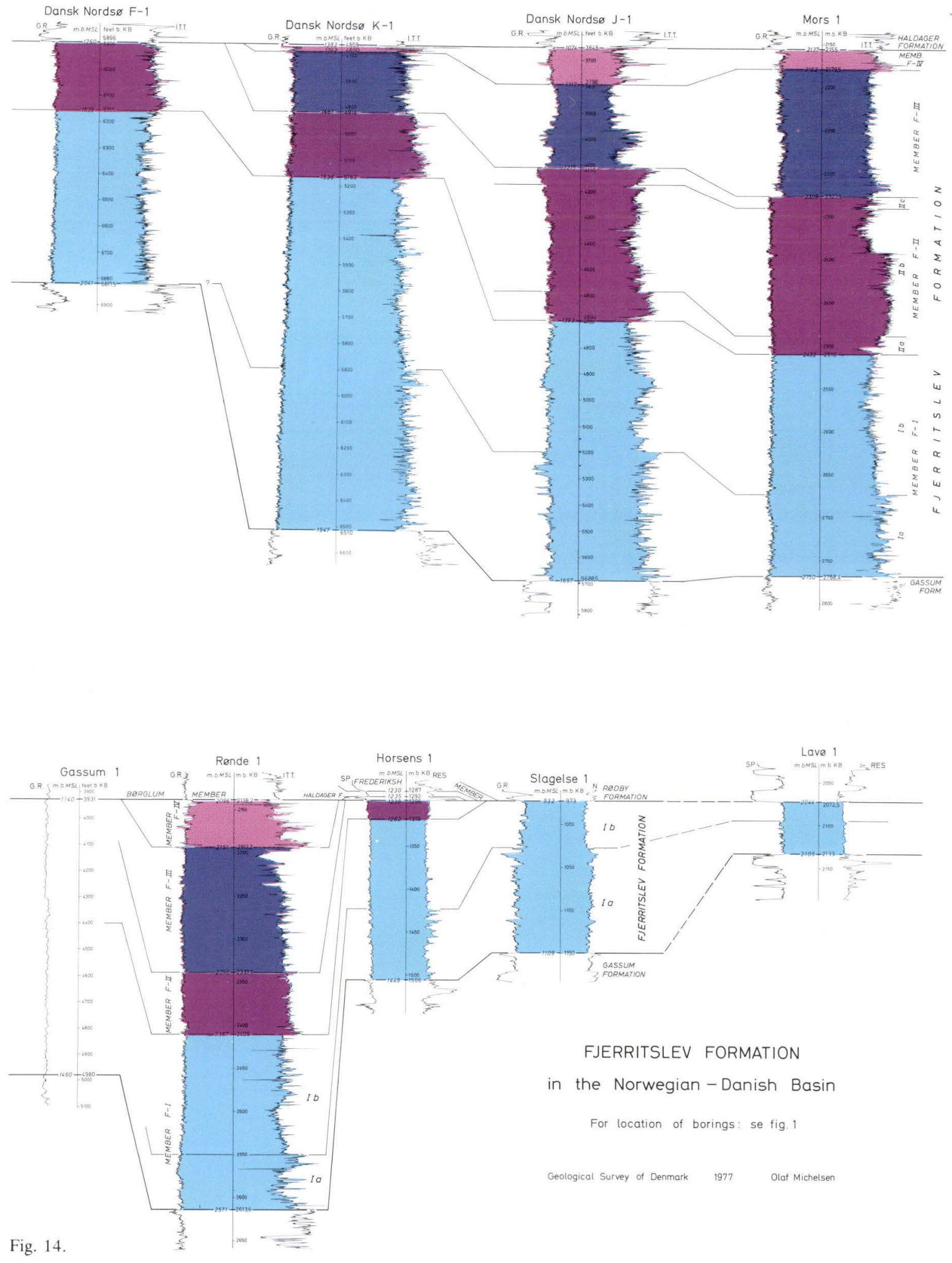


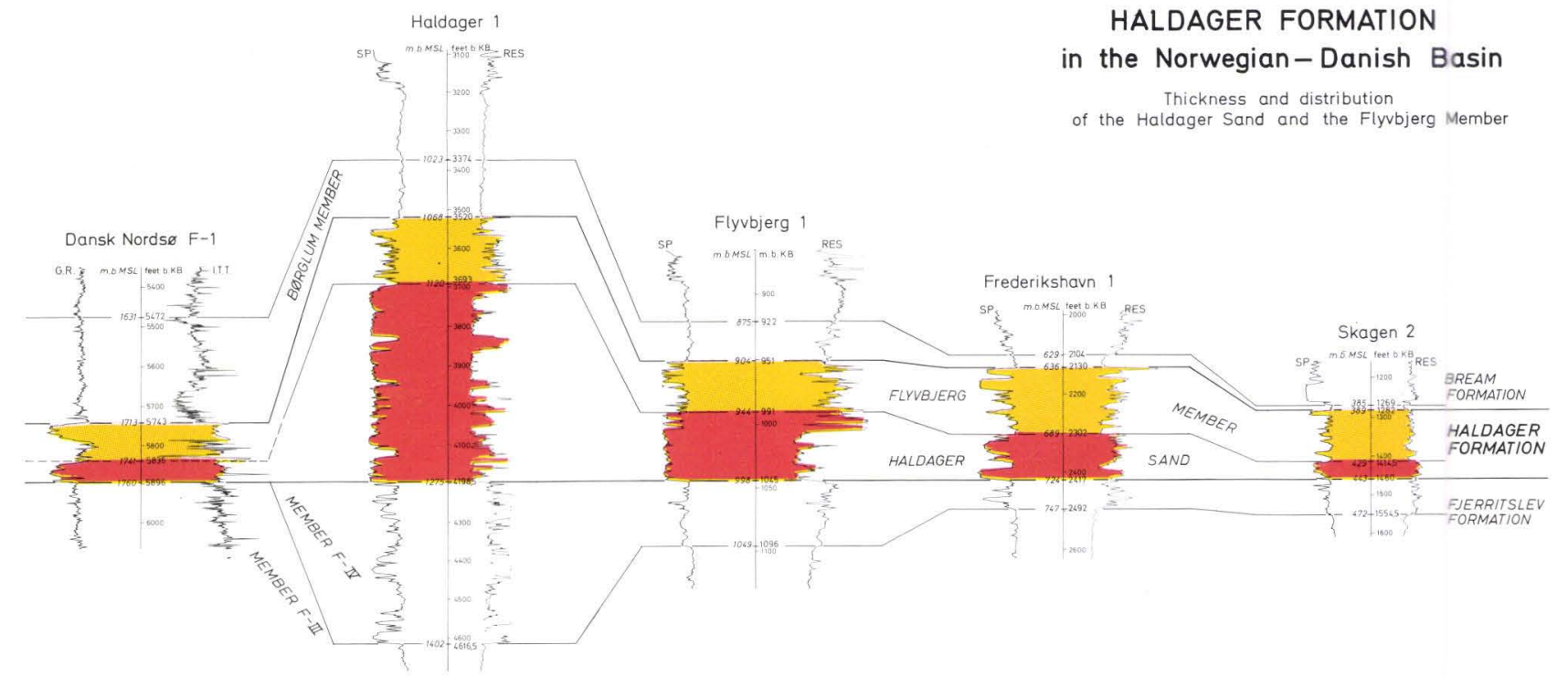

the Haldager Sand and the Flyvujerg Member
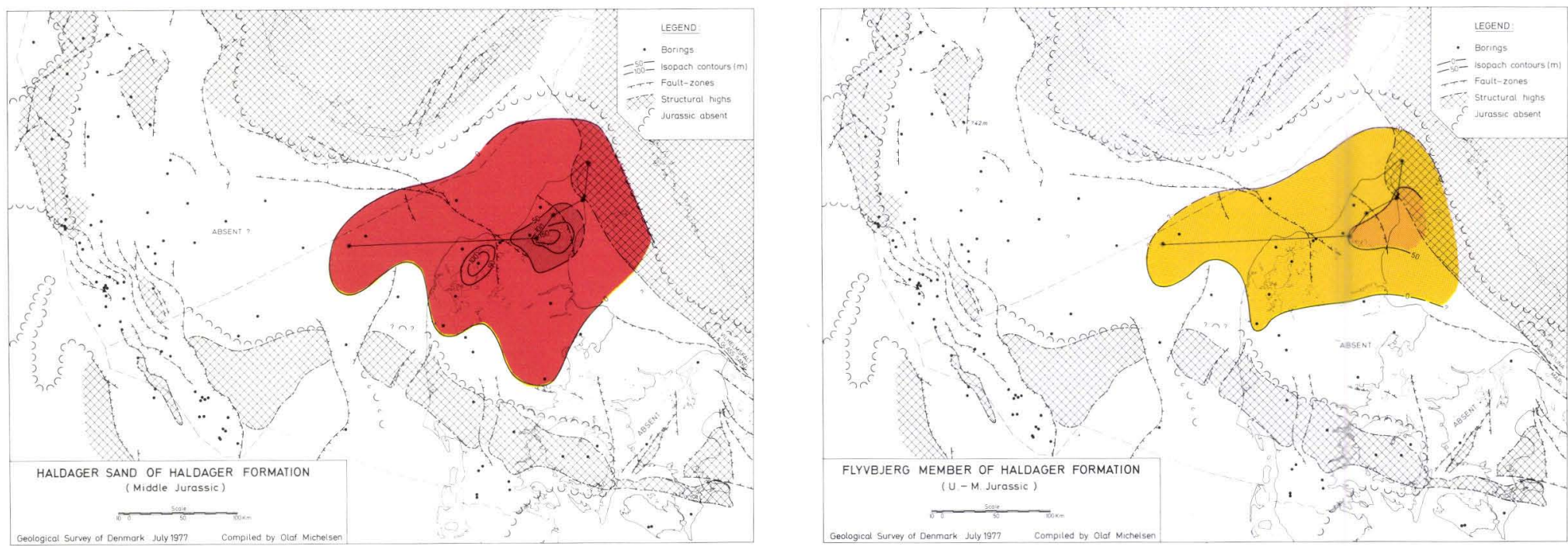

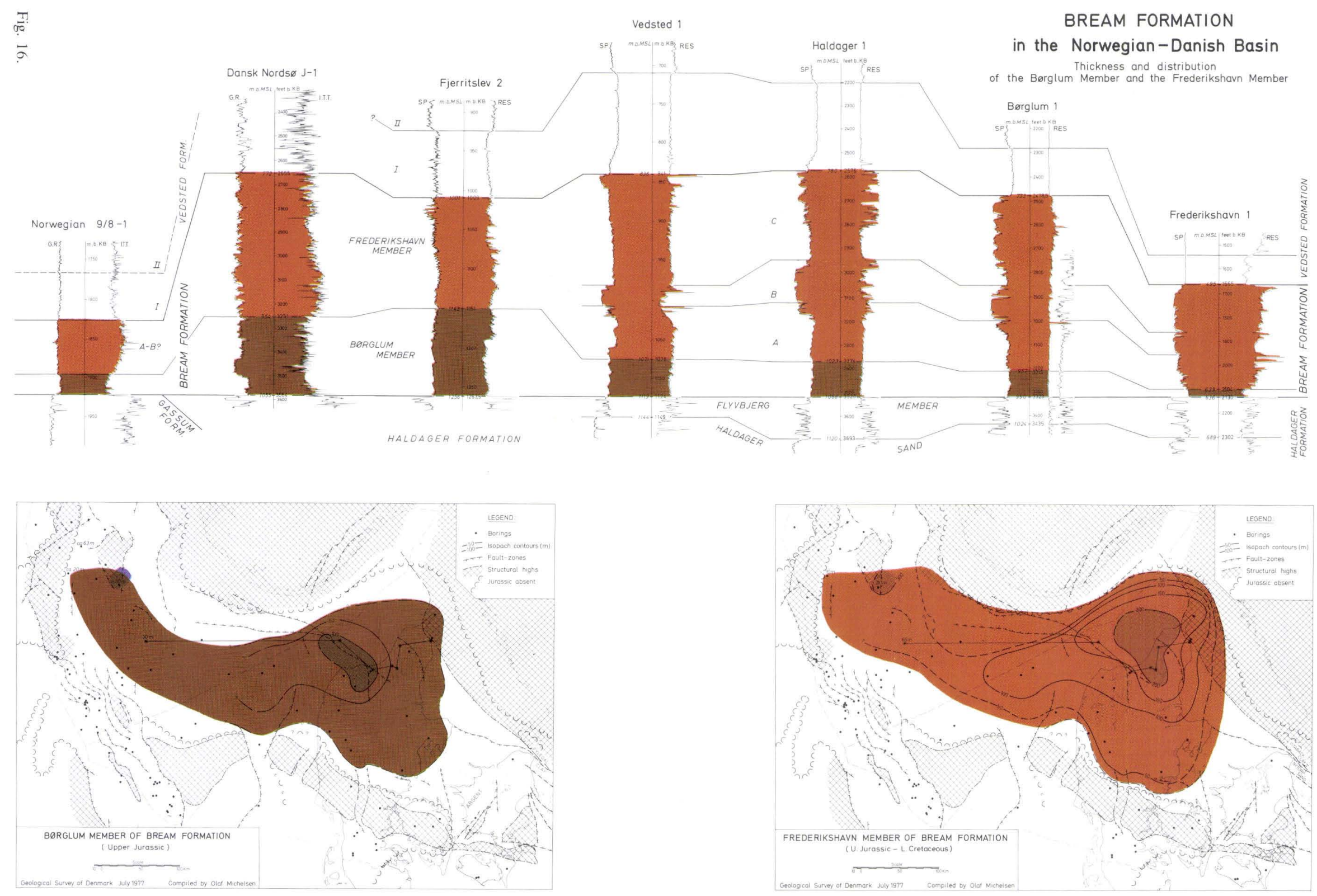

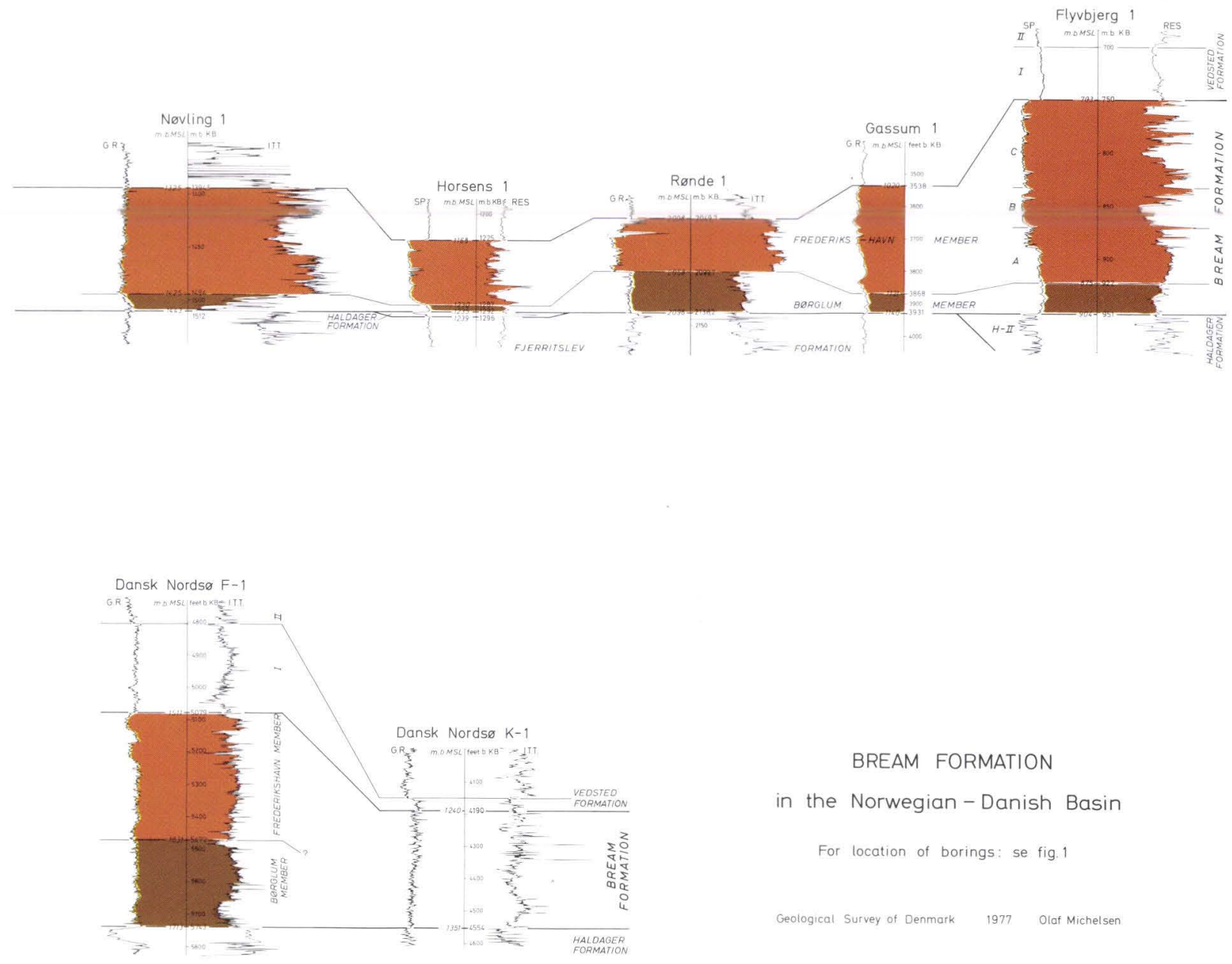

BREAM FORMATION

in the Norwegian-Danish Basin

For location of borings: se fig. 1

Geological Survey of Denmark 1977 Olaf Michelsen

Fig. 17. 